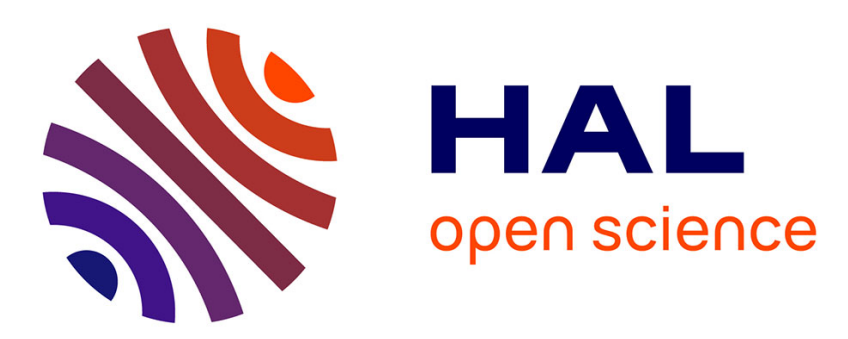

\title{
Synthesis, Coordination to Rh(I), and Hydroformylation \\ Catalysis of New $\beta$-Aminophosphines Bearing a Dangling Nitrogen Group: An Unusual Inversion of a Rh-Coordinated P Center
}

Jacques Andrieu, Philippe Richard, Jean-Michel Camus, Rinaldo Poli

\section{To cite this version:}

Jacques Andrieu, Philippe Richard, Jean-Michel Camus, Rinaldo Poli. Synthesis, Coordination to $\mathrm{Rh}(\mathrm{I})$, and Hydroformylation Catalysis of New $\beta$-Aminophosphines Bearing a Dangling Nitrogen Group: An Unusual Inversion of a Rh-Coordinated P Center. Inorganic Chemistry, 2002, 41 (15), pp.3876-3885. 10.1021/ic011035i . hal-03284120

\author{
HAL Id: hal-03284120 \\ https://hal.science/hal-03284120
}

Submitted on 20 Jul 2021

HAL is a multi-disciplinary open access archive for the deposit and dissemination of scientific research documents, whether they are published or not. The documents may come from teaching and research institutions in France or abroad, or from public or private research centers.
L'archive ouverte pluridisciplinaire HAL, est destinée au dépôt et à la diffusion de documents scientifiques de niveau recherche, publiés ou non, émanant des établissements d'enseignement et de recherche français ou étrangers, des laboratoires publics ou privés. 
Submitted to : Inorg. Chem.

\section{Synthesis, coordination to $\mathrm{Rh}(\mathrm{I})$, and hydroformylation catalysis \\ of new $\beta$-aminophosphines bearing a dangling nitrogen group:}

An unusual inversion of a Rh-coordinated P-center

Jacques Andrieu,* Philippe Richard, Jean-Michel Camus and Rinaldo Poli

Laboratoire de Synthèse et d'Electrosynthèse Organométalliques, Université de Bourgogne,

Faculté des Sciences "Gabriel", 6 Boulevard Gabriel, 21000 Dijon, France

Proofs to : Dr Jacques Andrieu

Laboratoire de Synthèse et d'Electrosynthèse Organométalliques

Université de Bourgogne, Faculté des Sciences "Gabriel"

6, Boulevard Gabriel, 21000 Dijon, France

e-mail : Jacques.Andrieu@u-bourgogne.fr

Keywords - Aminophosphines, rhodium, hydroformylation, P-epimerization, stereochemistry 


\section{Synopsis}

New $\beta, \gamma$ - and $\beta, \alpha-P, N, N$ ligands have been obtained by introduction of a second nitrogen function in a $\beta-\mathrm{P}, \mathrm{N}$ aminophosphine. These diaminophosphines adopt a $\kappa-P, \kappa-N$ coordination mode in $\mathrm{RhCl}(\mathrm{CO})(\mathrm{P}, \mathrm{N}, \mathrm{N})$ complexes, similar to $\beta-\mathrm{P}, \mathrm{N}$ ligands. In the case of the $\beta, \alpha-\mathrm{P}, \mathrm{N}, \mathrm{N}$ ligand, an unexpected P-atom epimerization has been observed for the $\mathrm{Rh}(\mathrm{I})$ complex. The catalytic activities in hydroformylation by the new $\mathrm{Rh}(\mathrm{I})$-diaminophosphine complexes are enhanced by the proximity of this additional uncoordinated nitrogen function.

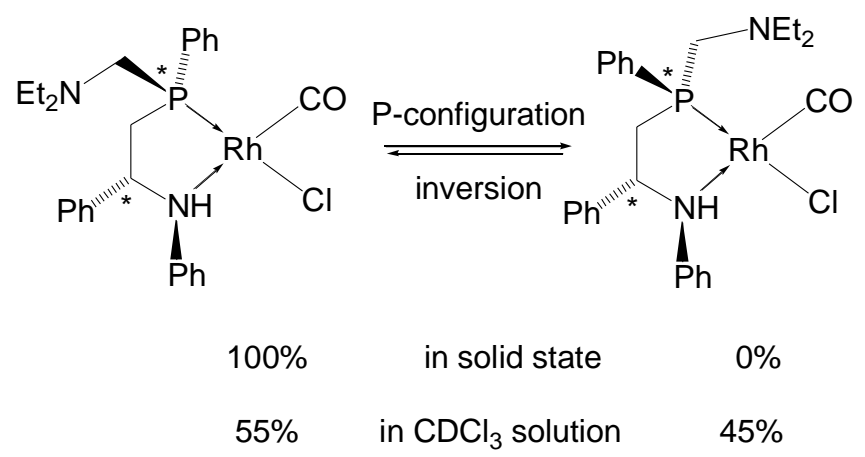




\begin{abstract}
Variants of the $\beta$-aminophosphine $\mathbf{L}^{1}\left[\mathrm{Ph}_{2} \mathrm{PCH}_{2} \mathrm{CH}(\mathrm{Ph}) \mathrm{NHPh}\right]$ containing additional nitrogen donor functions have been prepared. These functions are branched off the $\mathrm{C}$ atom adjacent to the $\mathrm{P}$ atom, or the $\mathrm{P}$ atom itself. Ligand $\left[\mathrm{Ph}_{2} \mathrm{PCH}\left(-o-\mathrm{C}_{6} \mathrm{H}_{4} \mathrm{NMe}_{2}\right) \mathrm{CH}(\mathrm{Ph}) \mathrm{NHPh}\right]$ has been obtained as a mixture of two diastereomers $\mathbf{L}^{\mathbf{3 A}}$ and $\mathbf{L}^{\mathbf{3 B}}$ by lithiation of $\mathbf{L}^{2}\left[\mathrm{Ph}_{2} \mathrm{PCH}_{2}\left(-o-\mathrm{C}_{6} \mathrm{H}_{4} \mathrm{NMe}_{2}\right)\right]$ with $n$ BuLi followed by $\mathrm{PhCH}=\mathrm{NPh}$ addition and hydrolysis. The diastereomers have been separated by fractional crystallization from ethanol. Ligand $\mathrm{Et}_{2} \mathrm{NCH}_{2} \mathrm{P}(\mathrm{Ph}) \mathrm{CH}_{2} \mathrm{CH}(\mathrm{Ph}) \mathrm{NHPh}$ has been obtained as a mixture of two diastereomers $\mathbf{L}^{\mathbf{5 A}}$ and $\mathbf{L}^{\mathbf{5 B}}$ starting with $\mathrm{P}-\mathrm{Ph}$ reductive cleavage of $\mathbf{L}^{\mathbf{1}}$ by lithium and subsequent hydrolysis to give $\mathrm{PhP}(\mathrm{H}) \mathrm{CH}_{2} \mathrm{CH}(\mathrm{Ph}) \mathrm{NHPh}$ (mixture of two diastereomers $\mathbf{L}^{4 \mathbf{A}}$ and $\left.\mathbf{L}^{\mathbf{4 B}}\right)$. The latter reacts with diethylamine and formaldehyde to afford the $\mathbf{L}^{\mathbf{5}}$ diastereomeric mixture. Complexes $\operatorname{RhCl}(\mathrm{CO})(\mathrm{L})\left(\mathrm{L}=\mathbf{L}^{\mathbf{3 A}}, \mathbf{1}^{\mathbf{A}} ; \mathbf{L}^{\mathbf{3 B}}, \mathbf{1}^{\mathbf{B}} ; \mathbf{L}^{\mathbf{5 A} / \mathbf{B}}, \mathbf{2}^{\mathrm{A} / \mathbf{B}}\right)$ were obtained by reaction of $\left[\mathrm{RhCl}(\mathrm{CO})_{2}\right]_{2}$ and the appropriate ligand or ligand mixture. Complexes $\mathbf{1}^{\mathbf{A}}, \mathbf{1}^{\mathbf{B}}$, and $\mathbf{2}^{\mathbf{A}}$ have been isolated in pure form and characterized by classical techniques and by single crystal X-ray diffraction. All structures exhibit a bidentate $\kappa-P, \kappa-N(\mathrm{NHPh})$ mode similar to the complex containing $\mathbf{L}^{\mathbf{1}}$. While complexes $\mathbf{1}^{\mathbf{A}}$ or $\mathbf{1}^{\mathbf{B}}$ are stable in $\mathrm{CDCl}_{3}$ solution, complex $\mathbf{2}^{\mathbf{A}}$ slowly converts to its diastereomer $\mathbf{2}^{\mathbf{B}}$. This unexpected epimerization appears to take place by inversion at the Rh-coordinated $\mathrm{P}$ center, an apparently unprecedented phenomenon. A mechanism based on a reversible $\mathrm{P}-\mathrm{C}$ bond oxidative addition is proposed. The influence of the pendant nitrogen function of the diaminophosphines $\mathbf{L}^{\mathbf{3 A}}$ and $\mathbf{L}^{\mathbf{5 A / B}}$ on the rhodium catalytic activity in styrene hydroformylation has been examined and compared to that of the aminophosphines $\mathbf{L}^{\mathbf{1}}$ or $\mathbf{L}^{\mathbf{2}}$. The observed trends are related to the basicity of the dangling amine function and to its proximity to the metal center.
\end{abstract}




\section{Introduction}

Aminophosphine ligands are being intensively investigated because of the catalytic applications of their corresponding $\mathrm{Ru},{ }^{1,2} \mathrm{Ni},{ }^{3,4} \mathrm{Rh}^{5-8}$ and $\mathrm{Pd}^{9-11}$ complexes. Although the preparation of chiral versions of $\beta-\mathrm{P}, \mathrm{N}$ ligands requires in general tedious multistep procedures, ${ }^{12-15}$ some have been shown to be efficient in asymmetric enantioselective allylic alkylations, ${ }^{16}$ hydroformylation $^{7}$ and hydrogenation. ${ }^{12}$

We have recently reported a novel and relatively simple synthetic procedure for the preparation of chiral $\beta$-aminophosphines, which consists of the nucleophilic addition of a phosphinomethyl carbanion onto an imine. This procedure is exemplified by the formation of ligand $\mathrm{Ph}_{2} \mathrm{PCH}_{2} \mathrm{CH}(\mathrm{Ph}) \mathrm{NHPh}\left(\mathbf{L}^{\mathbf{1}}\right)$, in Scheme $1 .{ }^{17}$ Ligands of this type have been shown to coordinate in a chelating fashion $\left(\kappa^{2}-P, N\right)$ and stereoselectively. However, we noted that only one of the two possible diastereomers is formed upon bidentate coordination of $\mathbf{L}^{\mathbf{1}}$ to $\mathrm{PdCl}_{2}$. Thus, there is $100 \%$ transmission of the chiral information to the nitrogen atom from the adjacent carbon atom, making ligands of this kind potentially useful in enantioselective catalysis.

$<$ Insert Scheme 1>

More recently, interest is developing toward the preparation of aminophosphines with additional functional groups ( $\mathrm{P}, \mathrm{N}, \mathrm{N}^{\prime} ; \mathrm{P}, \mathrm{N}, \mathrm{O}$; etc.). One reason for this interest is the possibility to use the third functionality for anchoring the ligand to a solid support. Solid-supported aminophosphines (Merrifield resin type) have in fact shown promise for catalytic applications in biphasic media. $^{18}$

In the case of $\beta$-P,N ligands of the pyridinylphosphine type, the $\kappa^{2}-P, N$ chelating behavior was shown to be reduced or even suppressed by the introduction of other donor functions which 
compete with the pyridine for coordination. ${ }^{19,20}$ This competition may result in a double hemilability behavior (termed "wiper" by Braunstein). ${ }^{21}$ For instance, the N,P,O ligand $\mathrm{C}_{5} \mathrm{H}_{3} \mathrm{~N}(2-$ $\mathrm{CH}_{2} \mathrm{P}(\mathrm{Ph})(-o$-anisyl $)\left(6-\mathrm{CH}_{3}\right)^{19}$ shows a reversible $\mathrm{P}, \mathrm{O}$ and $\mathrm{P}, \mathrm{N}$ chelate exchange in cationic complexes of rhodium, see Scheme 2, while a $\mathrm{P}, \mathrm{P}, \mathrm{N}, \mathrm{N}^{\prime}$ ligand $\left[\mathrm{Ph}_{2} \mathrm{PCH}(2-\mathrm{Py}) \mathrm{CH}(2-\mathrm{Py}) \mathrm{PPh}_{2}\right]$ shows a similar P,P',N and P,P',N' exchange for a Rh(I) complex. ${ }^{22}$ Also notable is the behavior of complex $\left[\mathrm{CuL}_{2}\right]^{+}\left[\mathrm{L}=\mathrm{N}, \mathrm{N}-\mathrm{CH}_{3}\left(-o-\mathrm{C}_{6} \mathrm{H}_{4}-\mathrm{CH}_{2} \mathrm{PPh}_{2}\right) \mathrm{NCH}_{2} \mathrm{CH}_{2} \mathrm{OH}\right]$, showing a double exchange between $\quad\left[\mathrm{Cu}(\mathrm{L}-\kappa-\mathrm{P})\left(\mathrm{L}-\kappa-P^{\prime}, \kappa-N^{\prime}, \kappa-O^{\prime}\right)\right]^{+} \quad$ and $\quad\left[\mathrm{Cu}(\mathrm{L}-\kappa-P, \kappa-N, \kappa-O)\left(\mathrm{L}-\kappa-P^{\prime}\right)\right]^{+}$forms, see Scheme $2 .^{23}$

$<$ Insert Scheme 2>

It has been reported that rhodium catalysts containing achiral $\beta$-aminophosphines have a greater activity when the ligand bears an ether $v s$ an alcohol function. ${ }^{8}$ The preparation of a P,N,N ligand with a chiral $\beta$-amino-phosphine moiety has not so far been considered. These ligands, however, could provide advantages linked to the different basicity of the residual (dangling) $\mathrm{N}$ function and to an increased steric control via the nitrogen substituents.

In this paper, we describe the synthesis of new types of $\beta$-aminophosphines $(\mathrm{P}, \mathrm{N}, \mathrm{N})$ bearing a dangling nitrogen group, the latter being linked either to the carbon atom adjacent to the phosphorus atom (type I) or directly to the phosphorus atom (type II), see Scheme 3. The type II ligands that we have developed have a chiral phosphorus atom. We shall refer to these ligands as $\beta, \omega$-diaminophosphines $(\omega=\alpha$ or $\gamma$ depending on the distance between the second $\mathrm{N}$ function and the $\mathrm{P}$ donor). 
We also report on (i) the coordination modes of these ligands in rhodium chloride carbonyl complexes showing an unusual rhodium-coordinated P-atom epimerization and (ii) their catalytic properties in styrene hydroformylation in comparison to related but simpler $\beta$ - or $\gamma$-P,N ligands.

\section{Experimental Section}

All manipulations were carried out under purified argon and in the dark using standard Schlenk techniques and all solvents were dried and deoxygenated prior to use. NMR measurements $\left({ }^{1} \mathrm{H},{ }^{13} \mathrm{C}\left\{{ }^{1} \mathrm{H}\right\}\right.$ and $\left.{ }^{31} \mathrm{P}\left\{{ }^{1} \mathrm{H}\right\}\right)$ were carried out with a Bruker $\mathrm{AC} 200$ spectrometer in $\mathrm{CDCl}_{3}$ at room temperature. The peak positions are reported with positive shifts in ppm downfield of TMS as calculated from the residual solvent peaks $\left({ }^{1} \mathrm{H}\right)$ or downfield of external $85 \% \mathrm{H}_{3} \mathrm{PO}_{4}\left({ }^{31} \mathrm{P}\right) \cdot{ }^{1} \mathrm{H}-{ }^{1} \mathrm{H}$ and ${ }^{13} \mathrm{C}-{ }^{1} \mathrm{H}$ correlation experiments were carried out on a Bruker DRX500 spectrometer. IR spectra were recorded in $\mathrm{CH}_{2} \mathrm{Cl}_{2}$ solution with a Bruker IFS $66 \mathrm{~V}$ spectrophotometer with $\mathrm{KBr}$ optics. Elemental analyses were carried out by the analytical service of the L.S.E.O. with a Fisons Instruments EA1108 analyzer. Compounds $\mathrm{PhCH}=\mathrm{NPh}, n-\mathrm{BuLi}\left(1.6 \mathrm{M}\right.$ in hexanes), $\mathrm{CH}_{2} \mathrm{O}(37 \%$ in water), $\mathrm{NHEt}_{2}$ (Aldrich), and $\left[\mathrm{RhCl}(\mathrm{CO})_{2}\right]_{2}$ (Strem) were commercial products and were used as received. The preparation of $\mathrm{Ph}_{2} \mathrm{PCH}_{2} \mathrm{CH}(\mathrm{Ph}) \mathrm{NHPh}\left(\mathbf{L}^{\mathbf{1}}\right)$ has been previously described. ${ }^{17}$ Ligand $\mathrm{Ph}_{2} \mathrm{PCH}_{2}\left(\mathrm{o}-\mathrm{C}_{6} \mathrm{H}_{4} \mathrm{NMe}_{2}\right)\left(\mathbf{L}^{2}\right)$ was prepared according to the literature procedure. ${ }^{24}$

Synthesis of $\mathbf{P h}_{2} \mathbf{P C H}\left(\mathbf{C}_{6} \mathrm{H}_{4} \mathbf{N M e} 2-2\right) \mathbf{C H}(\mathbf{P h}) \mathbf{N H P h},\left(\mathbf{L}^{3}\right)$. To a solution of $\mathbf{L}^{2}(1.0 \mathrm{~g}, 3.13$ $\mathrm{mmol})$ in $\mathrm{Et}_{2} \mathrm{O}(12 \mathrm{ml})$ was added $\mathrm{n}-\mathrm{BuLi}(2.0 \mathrm{ml}, 1.6 \mathrm{M}$ in hexanes). After refluxing for $4 \mathrm{~h}$, the resulting white suspension was cooled to room temperature, followed by slow addition of an $\mathrm{Et}_{2} \mathrm{O}$ solution $(15 \mathrm{ml})$ of N-benzylideneaniline $(0.567 \mathrm{~g}, 3.13 \mathrm{mmol})$. An orange solution immediately formed which then changed to a white suspension after a few minutes. After stirring for $12 \mathrm{~h}$, the mixture was hydrolysed by addition of a few $\mathrm{ml}$ of degassed water. The solvents were removed by evaporation under reduced pressure and the very viscous residue was dried for $1 / 2 \mathrm{~h}$ at $50^{\circ} \mathrm{C}$, 
followed by extraction with $2 \times 10 \mathrm{ml}$ of toluene and filtration through Celite to eliminate the lithium salts. The solution was evaporated to dryness under reduced pressure and the residue was dried for $1 \mathrm{~h}$ at $130^{\circ} \mathrm{C}$. No starting ligand $\mathbf{L}^{2}$ was detected in the crude product by NMR. After two crystallizations from hot ethanol $(20 \mathrm{ml})$ the pure $\mathbf{L}^{\mathbf{3 A}}$ ligand was recovered as white crystals (355 $\mathrm{mg}, 23 \%$ based on the starting ligand). ${ }^{1} \mathrm{H}$ NMR: 8.00-6.16 (24 H, m, aromatics), 5.44 (1H, s, br, $\mathrm{N} H$, exchange with $\left.\mathrm{D}_{2} \mathrm{O}\right), 5.03(2 \mathrm{H}, \mathrm{m}, \mathrm{NCH}+\mathrm{PCH}), 2.25\left(6 \mathrm{H}, \mathrm{s}, \mathrm{N}\left(\mathrm{CH}_{3}\right)\right) .{ }^{31} \mathrm{P}\left\{{ }^{1} \mathrm{H}\right\} \mathrm{NMR}:-6.83$. ${ }^{13} \mathrm{C}\left\{{ }^{1} \mathrm{H}\right\}$ NMR: 153.20-113.01 (30C, m, aromatics), $61.26\left(1 \mathrm{C}, \mathrm{d}, \mathrm{NCH},{ }^{2} J(\mathrm{P}, \mathrm{C})=18 \mathrm{~Hz}\right), 45.51$ $\left(2 \mathrm{C}, \mathrm{s}, \mathrm{CH}_{3} \mathrm{~N}\right), 44.45(1 \mathrm{C}, \mathrm{d}, \mathrm{PCH}, J(\mathrm{P}, \mathrm{C})=14 \mathrm{~Hz})$. IR: $3410\left(\mathrm{w}, \mathrm{br}, \mathrm{v}_{\mathrm{NH}}\right)$. The combined filtrates were concentrated to half volume. After 10 days at room temperature, pure white crystals of the second diastereomer $\mathbf{L}^{3 \mathbf{B}}$ were recovered $\left(315 \mathrm{mg}, 20 \%\right.$ based on the starting ligand). ${ }^{1} \mathrm{H}$ NMR: 7.70-6.31 $\left(24 \mathrm{H}, \mathrm{m}\right.$, aromatics), $4.93\left(1 \mathrm{H}, \mathrm{s}, \mathrm{br}, \mathrm{NH}\right.$, exchange with $\left.\mathrm{D}_{2} \mathrm{O}\right), 4.66(2 \mathrm{H}, \mathrm{s}, \mathrm{br}, \mathrm{NCH}+$ $\mathrm{PCH}), 2.10\left(6 \mathrm{H}, \mathrm{s}, \mathrm{CH} H_{3} \mathrm{~N}\right) .{ }^{31} \mathrm{P}\left\{{ }^{1} \mathrm{H}\right\}$ NMR: -4.05. ${ }^{13} \mathrm{C}\left\{{ }^{1} \mathrm{H}\right\}$ NMR: 148.40-113.95 (30C, m, aromatics), $60.68\left(1 \mathrm{C}, \mathrm{d}, \mathrm{NCH},{ }^{2} J(\mathrm{P}, \mathrm{C})=19 \mathrm{~Hz}\right), 45.89\left(3 \mathrm{C}, \mathrm{s}, \mathrm{PCH}+\mathrm{CH}_{3} \mathrm{~N}\right) . \mathrm{IR}: 3409(\mathrm{w}, \mathrm{br}$, $v_{\mathrm{NH}}$ ). Anal. Calcd. for $\mathrm{C}_{34} \mathrm{H}_{33} \mathrm{~N}_{2} \mathrm{P}: \mathrm{C} 81.57, \mathrm{H} 6.64$, N $5.60 \%$. Found: C 81.96, H 6.78, N 5.61 \%.

Synthesis of $\left[\mathbf{R h C l}(\mathbf{C O})\left(\mathbf{L}^{3 \mathbf{A}}-\mathbf{K}-\boldsymbol{P}, \boldsymbol{\kappa}-\boldsymbol{N}\right)\right], \mathbf{1}^{\mathrm{A}}$. To a mixture of $\left[\operatorname{RhCl}(\mathrm{CO})_{2}\right]_{2}(36 \mathrm{mg}, 0.092$ mmol) and $\mathbf{L}^{\mathbf{3 A}}$ (92 $\mathrm{mg}, 0.184 \mathrm{mmol}$ ) was added $5 \mathrm{ml}$ of THF. The resulting yellow solution was stirred for $1 \mathrm{~h}$. Addition of pentane afforded a yellow powder which was isolated by filtration and dried in vacuo (84 mg, $76 \%$ ). Yellow single crystals suitable for an X-ray diffraction analysis were obtained by slow diffusion from a THF/pentane mixture. ${ }^{1} \mathrm{H}$ NMR: 7.82-6.45 (24H, m, aromatics), $6.05\left(1 \mathrm{H}, \mathrm{d}, \mathrm{NH},{ }^{3} J(\mathrm{P}, \mathrm{H})=8 \mathrm{~Hz}\right), 5.88\left(1 \mathrm{H}, \mathrm{dd}, \mathrm{PCH},{ }^{2} J(\mathrm{P}, \mathrm{H})=8 \mathrm{~Hz},{ }^{3} J(\mathrm{H}, \mathrm{H})=13 \mathrm{~Hz}\right), 4.29(1 \mathrm{H}$, $\left.\mathrm{dd}, \mathrm{NCH},{ }^{3} J(\mathrm{P}, \mathrm{H})=23 \mathrm{~Hz},{ }^{3} J(\mathrm{H}, \mathrm{H})=13 \mathrm{~Hz}\right), 2.00\left(6 \mathrm{H}, \mathrm{s}, \mathrm{N}\left(\mathrm{CH}_{3}\right)\right) .{ }^{31} \mathrm{P}\left\{{ }^{1} \mathrm{H}\right\} \mathrm{NMR}: 74.0(\mathrm{~d}$, $\left.{ }^{1} J(\mathrm{Rh}, \mathrm{P})=170 \mathrm{~Hz}\right) .{ }^{13} \mathrm{C}\left\{{ }^{1} \mathrm{H}\right\} \mathrm{NMR}: 154.52-121.30$ (30C, m, aromatics), $75.10\left(1 \mathrm{C}, \mathrm{d}, \mathrm{NCH},{ }^{2} J(\mathrm{P}, \mathrm{C})\right.$ $=13 \mathrm{~Hz}), 48.63\left(1 \mathrm{C}, \mathrm{d}, \mathrm{PCH},{ }^{1} J(\mathrm{P}, \mathrm{C})=17 \mathrm{~Hz}\right) .45 .50\left(2 \mathrm{C}, \mathrm{s}, \mathrm{CH}_{3} \mathrm{~N}\right), \mathrm{IR}: 3249\left(\mathrm{w}, \mathrm{v}_{\mathrm{NH}}\right), 1983(\mathrm{vs}$, $v_{\mathrm{CO}}$ ). Anal. calcd. for $\mathrm{C}_{35} \mathrm{H}_{33} \mathrm{~N}_{2} \mathrm{OPRhCl}$ : C, 63.03; H, 4.98; N, 4.20 \%. Found: C, 62.90; H, 5.17; N, $4.38 \%$. 
Synthesis of $\left[\mathbf{R h C l}(\mathbf{C O})\left(\mathbf{L}^{\mathbf{3 B}}-\mathbf{K}-\boldsymbol{P}, \mathbf{K}-\boldsymbol{N}\right)\right], \mathbf{1}^{\mathbf{B}}$. To a mixture of $\left[\mathrm{RhCl}(\mathrm{CO})_{2}\right]_{2}(27 \mathrm{mg}, 0.069$ mmol) and $\mathbf{L}^{3 \mathbf{B}}$ (70 mg, $0.140 \mathrm{mmol}$ ) was added $5 \mathrm{ml}$ of THF. The yellow solution was stirred for $1 \mathrm{~h}$. Addition of pentane afforded a yellow powder which was isolated by filtration and dried in vacuo (71 mg, 78\%). Yellow single crystals suitable for an X-ray diffraction analysis were obtained by slow diffusion from THF/pentane mixture. ${ }^{1} \mathrm{H}$ NMR: 9.38-9.34 (24H, m, aromatics), $5.75(1 \mathrm{H}$, $\left.\mathrm{dd}, \mathrm{PCH},{ }^{2} J(\mathrm{P}, \mathrm{H})=15 \mathrm{~Hz},{ }^{3} J(\mathrm{H}, \mathrm{H})=5 \mathrm{~Hz}\right), 5.08\left(1 \mathrm{H}, \mathrm{d}, \mathrm{NH},{ }^{3} J(\mathrm{P}, \mathrm{H})=11 \mathrm{~Hz}\right), 4.41(1 \mathrm{H}, \mathrm{dd}, \mathrm{NCH}$, $\left.{ }^{3} J(\mathrm{P}, \mathrm{H})=12 \mathrm{~Hz},{ }^{3} J(\mathrm{H}, \mathrm{H})=5 \mathrm{~Hz}\right), 1.80\left(6 \mathrm{H}, \mathrm{s}, \mathrm{N}\left(\mathrm{CH}_{3}\right)\right) .{ }^{31} \mathrm{P}\left\{{ }^{1} \mathrm{H}\right\} \mathrm{NMR}: 69.36\left(\mathrm{~d},{ }^{1} J(\mathrm{Rh}, \mathrm{P})=172\right.$ Hz). ${ }^{13} \mathrm{C}\left\{{ }^{1} \mathrm{H}\right\}$ NMR: 144.77-122.61 (30C, m, aromatics), $74.45\left(1 \mathrm{C}, \mathrm{d}, \mathrm{NCH},{ }^{2} J(\mathrm{P}, \mathrm{C})=12 \mathrm{~Hz}\right)$, $47.32(1 \mathrm{C}, \mathrm{d}, \mathrm{PCH}, J(\mathrm{P}, \mathrm{C})=26 \mathrm{~Hz}), 45.10\left(2 \mathrm{C}, \mathrm{s}, \mathrm{CH}_{3} \mathrm{~N}\right)$. IR: $1993\left(\mathrm{vs}, \mathrm{v}_{\mathrm{CO}}\right)$ and $3271\left(\mathrm{w}, \mathrm{v}_{\mathrm{NH}}\right)$. Anal. calcd. for $\mathrm{C}_{35} \mathrm{H}_{33} \mathrm{~N}_{2} \mathrm{OPRhCl} . \mathrm{C}_{4} \mathrm{H}_{8} \mathrm{O}: \mathrm{C}, 63.38 ; \mathrm{H}, 5.59 ; \mathrm{N}, 3.79 \%$. Found; C, 64.12; H, 5.26; N, $3.74 \%$.

Synthesis of $\mathbf{H P}(\mathbf{P h}) \mathbf{C H}_{2} \mathbf{C H}(\mathbf{P h}) \mathbf{N H P h}, \mathbf{L}^{4 \mathrm{~A} / \mathrm{B}}$. To a colorless solution of $\mathbf{L}^{\mathbf{1}}(0.875 \mathrm{~g}, 2.30$ $\mathrm{mmol})$ in $20 \mathrm{ml}$ of THF was added lithium $(35 \mathrm{mg}, 5.0 \mathrm{mmol})$. After 4 days under stirring, the resulting solution was yellow-orange. Addition of $0.7 \mathrm{ml}$ of water afforded a colorless solution. All solvent were evaporated under reduced pressure and the white residue was dried in vacuo for $1 \mathrm{~h}$ at $50^{\circ} \mathrm{C}$, followed by extraction with $2 \times 10 \mathrm{ml}$ of toluene. After filtration through Celite, solvent evaporation afforded a viscous oil which was dried in vacuo at $100^{\circ} \mathrm{C}$ for $2 \mathrm{~h}$. NMR spectroscopic analyses of the crude product showed only the presence of the expected ligand $\mathbf{L}^{4}$ (1:1 mixture of diastereomers) $(0.670 \mathrm{~g}, 95 \%)$. Since the two isomers could not be separated, the NMR analyses did not allow an intimate structural assignment. ${ }^{1} \mathrm{H}-{ }^{1} \mathrm{H}$ and ${ }^{13} \mathrm{C}-{ }^{1} \mathrm{H}$ NMR correlation experiments allowed a complete peak assignment. ${ }^{1} \mathrm{H}$ NMR: 7.39-6.51 (15H+H', m, aromatics), $4.53\left(1 \mathrm{H}+\mathrm{H}^{\prime}\right.$, $\mathrm{m}, \mathrm{NCH}, 4.36\left(1 \mathrm{H}\right.$ or $\left.1 \mathrm{H}^{\prime}, \mathrm{dt}, \mathrm{PH},{ }^{1} J(\mathrm{PH})=215 \mathrm{~Hz},{ }^{3} J\left(\mathrm{H}, \mathrm{H}_{\mathrm{PCHa}}\right)={ }^{3} J\left(\mathrm{H}, \mathrm{H}_{\mathrm{PCHb}}\right)=7 \mathrm{~Hz}\right), 4.32(1 \mathrm{H}$ or $\left.1 \mathrm{H}^{\prime}, \mathrm{d}, \mathrm{NH},{ }^{3} J(\mathrm{H}, \mathrm{H})=6 \mathrm{~Hz}\right), 4.19\left(1 \mathrm{H}^{\prime}\right.$ or $1 \mathrm{H}, \mathrm{PH}, J(\mathrm{PH})=215 \mathrm{~Hz},{ }^{3} J\left(\mathrm{H}, \mathrm{H}_{\mathrm{PCHa}}\right)={ }^{3} J\left(\mathrm{H}, \mathrm{H}_{\mathrm{PCHb}}\right)$ $=7 \mathrm{~Hz}), 4.18\left(1 \mathrm{H}^{\prime}\right.$ or $\left.1 \mathrm{H}, \mathrm{d}, \mathrm{NH},{ }^{3} J(\mathrm{H}, \mathrm{H})=6 \mathrm{~Hz}\right), 2.47\left(2 \mathrm{H}+\mathrm{H}^{\prime}, \mathrm{PCH}, \mathrm{m}\right) .{ }^{31} \mathrm{P}\left\{{ }^{1} \mathrm{H}\right\} \mathrm{NMR}:-62.00$ (s, P+P'). ${ }^{31} \mathrm{P}$ NMR: - $62.00\left(\mathrm{~d},{ }^{1} J(\mathrm{P}, \mathrm{H})=211 \mathrm{~Hz}\right) .{ }^{13} \mathrm{C}\left\{{ }^{1} \mathrm{H}\right\}$ NMR: 147.11-113.57 (15C+C', m, 
aromatics), $57.18\left(1 \mathrm{C}+\mathrm{C}^{\prime}, \mathrm{d}, \mathrm{NCH},{ }^{2} J(\mathrm{P}, \mathrm{C})=9 \mathrm{~Hz}\right), 34.04\left(1 \mathrm{C}\right.$ or $\left.1 \mathrm{C}^{\prime}, \mathrm{d}, \mathrm{PCH}, J(\mathrm{P}, \mathrm{C})=15.5 \mathrm{~Hz}\right)$, $33.07\left(1 \mathrm{C}^{\prime}\right.$ or $\left.1 \mathrm{C}, \mathrm{d}, \mathrm{PCH}, J(\mathrm{P}, \mathrm{C})=15.5 \mathrm{~Hz}\right)$. An elemental analysis could not be carried out because of the combined air sensitivity and high viscosity. The mixture was used for the synthesis below without further purification.

Synthesis of $\operatorname{Et}_{2} \mathrm{NCH}_{2} \mathbf{P}(\mathbf{P h}) \mathrm{CH}_{2} \mathrm{CH}(\mathrm{Ph}) \mathbf{N H P h}, \mathrm{L}^{5}$. The $\mathbf{L}^{4}$ diastereomeric mixture obtained in the above procedure $(0.670 \mathrm{~g}, 2.20 \mathrm{mmol})$ was dissolved in $10 \mathrm{ml}$ of degassed ethanol. Diethylamine $(260 \mu \mathrm{l}, 2.50 \mathrm{mmol})$ was added and the resulting solution was stirred for $10 \mathrm{~min}$. Formaldehyde in water $(195 \mu \mathrm{l}, 2.50 \mathrm{mmol})$ was then added. After $10 \mathrm{~min}$ a white precipitate appeared. After $2 \mathrm{~h}$ stirring at room temperature, the suspension was cooled to $0^{\circ} \mathrm{C}$ for $20 \mathrm{~min}$ and then filtered. The resulting white powder was dried in vacuo for $4 \mathrm{~h}$ at room temperature. $(0.751 \mathrm{~g}$, $83 \%)$. By ${ }^{1} \mathrm{H}$ and ${ }^{31} \mathrm{P}\left\{{ }^{1} \mathrm{H}\right\}$ NMR spectroscopic analyses, the product consists of a mixture of two diastereomers $\mathbf{L}^{\mathbf{5 A}}$ and $\mathbf{L}^{\mathbf{5 B}}$ in a $3: 2$ ratio. The ${ }^{1} \mathrm{H}-{ }^{1} \mathrm{H}$ and ${ }^{13} \mathrm{C}-{ }^{1} \mathrm{H}$ NMR correlation experiments allowed a complete peak assignment. The attribution of the resonances for each isomer was possible following the separation of the rhodium complexes of the ligands (see next section). NMR properties of compound $\mathbf{L}^{5 \mathrm{~A}}:{ }^{1} \mathrm{H}$ NMR: 7.59-6.31 $(15 \mathrm{H}$, aromatics $+1 \mathrm{H}, \mathrm{NH}), 4.42(1 \mathrm{H}, \mathrm{CHN}, \mathrm{m})$, $2.89\left(8 \mathrm{H}\right.$, all $\left.\mathrm{CH}_{2}, \mathrm{~m}\right), 1.12\left(3 \mathrm{H}, \mathrm{CH}_{3}, \mathrm{t}\right) .{ }^{31} \mathrm{P}\left\{{ }^{1} \mathrm{H}\right\}$ NMR: $-35.86(\mathrm{~s}) .{ }^{13} \mathrm{C}\left\{{ }^{1} \mathrm{H}\right\} \mathrm{NMR}: 147.11-113.04$ (m, aromatics), $57.78\left(2 \mathrm{C}, \mathrm{s}, \mathrm{CH}_{3} \mathrm{CH}_{2} \mathrm{~N}\right), 57.06\left(1 \mathrm{C}, \mathrm{d}, \mathrm{CH}_{2} \mathrm{CHN},{ }^{2} \mathrm{~J}(\mathrm{PC})=20 \mathrm{~Hz}\right), 48.50(1 \mathrm{C}, \mathrm{d}$, $\left.\mathrm{PCH}_{2} \mathrm{~N},{ }^{1} J(\mathrm{P}, \mathrm{C})=7 \mathrm{~Hz}\right), 41.60\left(1 \mathrm{C}, \mathrm{d}, \mathrm{PCH}_{2} \mathrm{C},{ }^{1} J(\mathrm{P}, \mathrm{C})=19 \mathrm{~Hz}\right), 11.16\left(2 \mathrm{C}, \mathrm{s}, \mathrm{CH}_{3}\right) . \mathrm{NMR}$ properties of compound $\mathbf{L}^{\mathbf{5 B}}$ : ${ }^{1} \mathrm{H}$ NMR: 7.59-6.31 (15H, aromatics), $5.82\left(1 \mathrm{H}, \mathrm{d}, \mathrm{NH},{ }^{3} J(\mathrm{H}, \mathrm{H})=5\right.$ $\mathrm{Hz}), 4.73(1 \mathrm{H}, \mathrm{CHN}, \mathrm{m}), 2.89\left(8 \mathrm{H}\right.$, all $\left.\mathrm{CH}_{2}, \mathrm{~m}\right), 1.05\left(3 \mathrm{H}, \mathrm{CH}_{3}, \mathrm{t}\right) .{ }^{31} \mathrm{P}\left\{{ }^{1} \mathrm{H}\right\} \mathrm{NMR}:-43.35$ (s). ${ }^{13} \mathrm{C}\left\{{ }^{1} \mathrm{H}\right\}$ NMR: 147.11-113.04 (m, aromatics), $57.46\left(2 \mathrm{C}, \mathrm{s}, \mathrm{CH}_{3} \mathrm{CH}_{2} \mathrm{~N}\right), 56.03\left(1 \mathrm{C}, \mathrm{d}, \mathrm{CH}_{2} \mathrm{CHN}\right.$, $\left.{ }^{2} J(\mathrm{P}, \mathrm{C})=14 \mathrm{~Hz}\right), 48.21\left(1 \mathrm{C}, \mathrm{d}, \mathrm{PCH}_{2} \mathrm{~N},{ }^{1} J(\mathrm{P}, \mathrm{C})=8 \mathrm{~Hz}\right), 39.73\left(1 \mathrm{C}, \mathrm{d}, \mathrm{PCH}_{2} \mathrm{C},{ }^{1} J(\mathrm{P}, \mathrm{C})=19 \mathrm{~Hz}\right)$, $11.45\left(2 \mathrm{C}, \mathrm{s}, \mathrm{CH}_{3}\right.$ ). IR: 3418 (w) and 3242 (w) (both $v_{\mathrm{NH}}$ ). Anal. calcd. for $\mathrm{C}_{25} \mathrm{H}_{31} \mathrm{~N}_{2} \mathrm{P}$ (390.50): C, 76.89; H, 8.00; N, $7.17 \%$. Found: C, 76.72; H, 7.75; N, 7.15\%. 
Synthesis of $\left[\operatorname{RhCl}(\mathrm{CO})\left(\mathrm{L}^{5 \mathrm{~A}}-\mathrm{\kappa}-P, \kappa-N\right)\right], 2^{\mathrm{A}}$, and $\left[\operatorname{RhCl}(\mathrm{CO})\left(\mathrm{L}^{5 \mathrm{~B}}-\mathrm{\kappa}-P, \kappa-N\right)\right], 2^{\mathrm{B}}$. A compound $\left[\mathrm{RhCl}(\mathrm{CO})_{2}\right]_{2}(53 \mathrm{mg}, 0.136 \mathrm{mmol})$ and $\mathbf{L}^{\mathbf{5}}$ (3:2 diastereomeric mixture) from the above procedure (107 mg, $0.273 \mathrm{mmol})$ were dissolved in $5 \mathrm{ml}$ of THF. The brown-red solution was stirred for $1 \mathrm{~h}$. Addition of pentane under stirring afforded a yellow-brown powder which was isolated by filtration and dried in vacuo. $(97 \mathrm{mg}, 64 \%)$. A ${ }^{31} \mathrm{P}$ NMR spectrum of the crude product indicated a mixture of $2^{\mathbf{B}} / 2^{\mathrm{A}}$ in a $45: 55$ ratio in the presence of a byproduct $\mathbf{2}^{2}$. The same ratio of products was also observed in solution after $10 \mathrm{~min}$ when the reaction was carried out in $\mathrm{CDCl}_{3}$ solution instead of THF.

Diastereomer $2^{\mathrm{A}}$ was isolated by two routes. The first procedure consisted of a crystallization from $\mathrm{CH}_{2} \mathrm{Cl}_{2}$ /pentane, affording pure $\mathbf{2}^{\mathrm{A}}$ as yellow-red single crystals. The second procedure consisted of the addition of a few $\mathrm{ml}$ of toluene to the crude mixture, followed by cooling the resulting solution to $-30^{\circ} \mathrm{C}$ for a few days. This procedure afforded a 79:21 mixture (by integration of the ${ }^{31} \mathrm{P}$ resonances) of complexes $\mathbf{2}^{\mathbf{A}}$ and $\mathbf{2}^{\prime}$ as a yellow-brown powder in a higher yield (52 $\mathrm{mg}$, 25\%). Compound $2^{\mathrm{A}}$. ${ }^{1} \mathrm{H}$ NMR: 8.13-7.00 (15H, m, aromatics), $6.12(1 \mathrm{H}, \mathrm{NH}, \mathrm{s}, \mathrm{br}), 4.68(1 \mathrm{H}$, $\mathrm{CHN}, \mathrm{s}, \mathrm{br}), 3.34-3.09\left(8 \mathrm{H}\right.$, all $\mathrm{CH}_{2}$ groups, m), $1.12\left(3 \mathrm{H}, \mathrm{CH}_{3}, \mathrm{~s}, \mathrm{br}\right) .{ }^{31} \mathrm{P}\left\{{ }^{1} \mathrm{H}\right\} \mathrm{NMR}: 42.39$ (d, $\left.{ }^{1} J(\mathrm{Rh}, \mathrm{P})=166 \mathrm{~Hz}\right)$. No ${ }^{13} \mathrm{C}\left\{{ }^{1} \mathrm{H}\right\}$ NMR data could be obtained due to the appearance of a decomposition product after ca. $5 \mathrm{~h}$ in $\mathrm{CDCl}_{3}$. IR: 3262 (w, $\mathrm{v}_{\mathrm{NH}}$ ), 1985 (vs, $\mathrm{v}_{\mathrm{CO}}$ ). Compound 2'. ${ }^{31} \mathrm{P}\left\{{ }^{1} \mathrm{H}\right\}$ NMR: $47.36\left(\mathrm{~d},{ }^{1} J(\mathrm{Rh}, \mathrm{P})=163 \mathrm{~Hz}\right) .{ }^{1} \mathrm{H}$ NMR and IR data for $\mathbf{2}^{\mathbf{B}}$ were deduced by difference from the spectra of the crude mixture. Compound $\mathbf{2}^{\mathbf{B}}$. ${ }^{1} \mathrm{H}$ NMR: 8.13-7.00 (15H, m, aromatics), $6.39(1 \mathrm{H}, \mathrm{NH}, \mathrm{s}, \mathrm{br}), 3.83(1 \mathrm{H}, \mathrm{CHN}, \mathrm{s}, \mathrm{br}), 3.34-3.09$ (8H, all $\mathrm{CH}_{2}$ groups, m), 1.12 (3H, $\mathrm{CH}_{3}$, s, br). IR: $3249\left(\mathrm{w}, \mathrm{v}_{\mathrm{NH}}\right), 1983$ (vs, v $\left.\mathrm{CO}\right) .{ }^{31} \mathrm{P}\left\{{ }^{1} \mathrm{H}\right\}$ NMR: $57.51\left(\mathrm{~d},{ }^{1} J(\mathrm{Rh}, \mathrm{P})=160 \mathrm{~Hz}\right)$. Anal. calcd. for $\mathrm{C}_{26} \mathrm{H}_{31} \mathrm{~N}_{2} \mathrm{OPRhCl}$ : C, 56.07; H, 5.61; N, $5.03 \%$. Found: C, 56.12; H, 5.62; N, 5.12 $\%$.

Crystal structure analyses of complexes $1^{\mathrm{A}}, \mathbf{1}^{\mathrm{B}}$ and $2^{\mathrm{A}}$. Intensity data were collected on a Nonius Kappa CCD at $110 \mathrm{~K}$ for all complexes. The structures were solved by the heavy atom 
method (SHELXS-97) ${ }^{25}$ and refined by full-matrix least-squares methods (SHELXL-97) ${ }^{26}$ with the aid of the WINGX program. ${ }^{27}$ Except for some carbon atoms in $\mathbf{1}^{\mathbf{B}}$, non-hydrogen atoms were anisotropically refined. In $\mathbf{1}^{\mathbf{A}}$, the hydrogen atoms belonging to the complex were located in the final difference Fourier maps and refined freely with their temperature factors fixed at 1.2 or 1.5 (for $\mathrm{CH}_{3}$ ) times the Ueq of their parent atoms. The hydrogen atoms of the solvate (one THF molecule) were included in calculated positions and refined in a riding model. In $\mathbf{1}^{\mathbf{B}}$, the two phenyl groups attached to the phosphorus atom were found to be disordered over two positions. The occupancies of the pairs of phenyl groups converged to $\mathrm{m} 1=0.55$ and $\mathrm{m} 2=1-\mathrm{m} 1$ and one of the disordered phenyl groups was left isotropic. Two THF solvate molecules were located in the Fourier map, one in general position and the other around an inversion center. These molecules were badly disordered and any attempt to refine a model failed. Thus a BYPASS procedure, implemented in the PLATON program, ${ }^{28}$ was used to handle this problem. In this procedure the contribution of the solvent (1.5 THF molecules) electron density was substracted from the structure factor. The refinement was carried out with this solvent-corrected data set. In $\mathbf{2}^{\mathbf{A}}$, the hydrogen atoms were located in the final difference Fourier maps and refined freely with their temperature factors fixed at 1.2 or $1.5\left(\right.$ for $\left.\mathrm{CH}_{3}\right)$ times the Ueq of their parent atoms. Crystallographic data and selected geometrical parameters for all compounds are reported in Table 1 and Table 2, respectively.

<Insert Table 1 and Table 2>

Catalytic runs. The hydroformylation reactions were carried out in a 300-ml stainless-steel Parr autoclave equipped with a magnetic drive and an internal glass vessel. The temperature was controlled by a rigid heating mantle and by a single loop cooling coil. The autoclave was purged three times under vacuum/argon before introducing the catalytic solution and the styrene. The 
$\mathrm{CO} / \mathrm{H}_{2}$ mixture in a 1:1 ratio was prepared by mixing the pure gases in a $500-\mathrm{ml}$ stainless steel cylinder before introduction into the autoclave at the desired pressure. Aliquots of the mixture were withdrawn periodically, rotary evaporated at room temperature, and the resulting yellow-orange residue was analyzed by ${ }^{1} \mathrm{H}$ NMR spectroscopy (see Table 3).

$<$ Insert Table 3>

\section{Results and Discussion}

\section{Synthesis of $\beta, \gamma$-diaminophosphines}

The new ligand $\mathrm{Ph}_{2} \mathrm{PCH}\left(o-\mathrm{C}_{6} \mathrm{H}_{4} \mathrm{NMe}_{2}\right) \mathrm{CH}(\mathrm{Ph}) \mathrm{NHPh}, \mathbf{L}^{3}$ (as a mixture of two racemic diastereomers), has been synthesized by an extension of our previous work which led to the formation of the $\beta-\mathrm{P}, \mathrm{N}$ ligand $\mathbf{L}^{\mathbf{1}}$ by nucleophilic addition of $\mathrm{Ph}_{2} \mathrm{PCH}_{2}{ }^{-}$to the $\mathrm{C}=\mathrm{N}$ double bond of benzaldimine (Scheme 1). ${ }^{17}$ Since it is known that the aminophosphines $\mathrm{Ph}_{2} \mathrm{PCH}_{2}\left(o-\mathrm{C}_{6} \mathrm{H}_{4} \mathrm{NRR}^{\prime}\right)$ $\left(\mathrm{R}, \mathrm{R}^{\prime}=\mathrm{CH}_{3}, \mathrm{CH}_{2} \mathrm{CH}_{2} \mathrm{OH}\right)$ can easily undergo benzylic deprotonation with n-BuLi, ${ }^{23}$ we have now applied the same procedure starting from the known $O$-diphenylphosphino- $N, N$ dimethylbenzylamine $\left(\mathbf{L}^{2}\right){ }^{24}$ The deprotonation reaction leads to the $\mathrm{Ph}_{2} \mathrm{PCH}^{-}\left(\mathrm{Li}^{+}\right)\left(o-\mathrm{C}_{6} \mathrm{H}_{4}-\right.$ $\left.\mathrm{N}\left(\mathrm{CH}_{3}\right)_{2}\right)$ anion which reacts with $\mathrm{PhCH}=\mathrm{NPh}$ to afford a 1:1 mixture (by NMR) of the $\mathbf{L}^{\mathbf{3 A}}$ $\left(R_{C 1}, R_{C 2}\right) /\left(S_{C 1}, S_{C 2}\right)$ and $\mathbf{L}^{3 \mathbf{B}}\left(S_{C 1}, R_{C 2}\right) /\left(R_{C 1}, S_{C 2}\right)$ ligands after hydrolysis in $48 \%$ yields, see Scheme 4. Both diastereoisomers could be obtained in a pure form by fractional crystallisation from ethanol. The relative configuration is known for both isomers from the X-ray analysis of the corresponding $\mathrm{Rh}(\mathrm{I})$ derivatives $\mathbf{1}$ (vide infra). 


\section{Synthesis of $\beta, \alpha$-diaminophosphines}

The new ligand $\mathrm{Et}_{2} \mathrm{NCH}_{2} \mathrm{P}(\mathrm{Ph}) \mathrm{CH}_{2} \mathrm{CH}(\mathrm{Ph}) \mathrm{NHPh}, \mathbf{L}^{\mathbf{5}}$ (as a mixture of two racemic diastereomers), is available by $\mathrm{P}$-functionalisation of the $\beta-\mathrm{P}, \mathrm{N} \mathbf{L}^{\mathbf{1}}$ ligand in only two steps as shown in Scheme 5. The first step consists of the reductive cleavage of one P-C(phenyl) bond by lithium. Alkali metals are known to perform this reaction selectively and under mild conditions in ether or liquid $\mathrm{NH}_{3} .{ }^{29-31}$ The presence of the secondary amine function in $\mathbf{L}^{\mathbf{1}}$ does not interfere with the reaction. After hydrolysis, a 1:1 mixture of the diastereomeric $\mathbf{L}^{\mathbf{4 A}}\left(R_{P 1}, S_{C}\right) /\left(S_{P}, R_{C}\right)$ and $\mathbf{L}^{\mathbf{4 B}}$ $\left(R_{P 1}, R_{C}\right) /\left(S_{P}, S_{C}\right)$ ligands containing a new $\mathrm{P}-\mathrm{H}$ bond was obtained in excellent yields (95\%) (see

Scheme 5). The presence of the $\mathrm{P}-\mathrm{H}$ bond was confirmed by ${ }^{31} \mathrm{P}\left\{{ }^{1} \mathrm{H}\right\}$ NMR resonances (accidentally overlapping at $-62 \mathrm{ppm}$ for the two isomers) and ${ }^{1} \mathrm{H}$ spectra. The formation of the new asymmetric center on the $\mathrm{P}$ atom leads to the formation of two diastereomers without any diastereomeric excess. The second step consists of a standard Mannich-type addition to formaldehyde, similar to the previously reported synthesis of $\mathrm{Ph}_{2} \mathrm{PCH}_{2} \mathrm{NR}_{2}$ from $\mathrm{Ph}_{2} \mathrm{PH}, \mathrm{R}_{2} \mathrm{NH}$ and $\mathrm{CH}_{2} \mathrm{O},{ }^{15}$ and gives rise to $\mathbf{L}^{\mathbf{5 A}}$ and $\mathbf{L}^{\mathbf{5 B}}$ in a ca. 3:2 ratio. This step is also characterized by excellent yields and chemoselectivity. The two diastereomers could not be separated from each other. It is worth underlining that this synthetic procedure is more convenient and efficient relative to that previously described for simpler, achiral $\beta, \alpha$-diaminophosphines, ${ }^{15}$ since it avoids the use of tedious $\mathrm{PhPH}_{2}$ or $\mathrm{Na} / \mathrm{NH}_{3}$ reagents.

\section{<Insert Scheme 5>}

The second step of Scheme 5 was also carried out at $-78^{\circ} \mathrm{C}$ in an attempt to increase the diastereoselectivity. However, the same diastereomeric excess was obtained after the work-up, as indicated by the NMR analyses. Moreover, in contrast to the diastereomeric mixture for $\mathbf{L}^{\mathbf{3}}$, 
different separation attempts of the $\mathbf{L}^{\mathbf{5}}$ isomers by crystallization from hot ethanol (cooling to either room temperature or $-30^{\circ} \mathrm{C}$ ) did not alter the diastereomeric ratio. These observations could be the consequence of a rapid interconversion, which in fact slowly takes place when the ligand is coordinated to a $\mathrm{Rh}(\mathrm{I})$ center in complexes $\mathbf{2}^{\mathbf{A}}$ and $\mathbf{2}^{\mathbf{B}}$ (vide infra). However, the relative intensities and shape of the $\mathrm{PCH}$ signals in the ${ }^{1} \mathrm{H}$ NMR spectrum in $\mathrm{C}_{6} \mathrm{D}_{6}$ solution does not change in the 20$60^{\circ} \mathrm{C}$ range, in disagreement with such proposal. In addition, it is well known that the pyramidal inversion barriers for tertiary phosphines are rather large. ${ }^{32}$ Although the NMR properties of $\mathbf{L}^{\mathbf{5 A}}$ and $\mathbf{L}^{5 \mathbf{B}}$ are rather similar, the two ligands show markedly different IR absorbtions in the $v_{\mathrm{N}-\mathrm{H}}$ region. We attribute this difference to the greater ability of one of the two diastereomers to establish an intramolecular $\mathrm{N}-\mathrm{H}^{\cdots} \mathrm{N}$ hydrogen bond between the NHPh group as a proton donor and the $\mathrm{NEt}_{2}$ group as a proton acceptor, see Scheme 6.

\section{<Insert Scheme 6>}

\section{Coordination of ligands $L^{3 \mathrm{~A} / \mathrm{B}}$ to $R \mathbf{R h}(\mathrm{I})$}

The reaction between the $\mathbf{L}^{3}$ ligands with $\left[\mathrm{RhCl}(\mathrm{CO})_{2}\right]_{2}$ led to the stereospecific formation of complexes 1, see Scheme 7. In each case, the presence of only one broad carbonyl absorption band at ca. $1990 \mathrm{~cm}^{-1}$ is consistent with a square planar monocarbonyl rhodium chloride structure bearing a P,N chelating ligand. However, the NMR analysis does not provide a clear indication of the chelating nature of the $\alpha, \gamma$-diaminophosphine ligand. $\mathrm{N}$-coordination by either the $\mathrm{NH}$ or the $\mathrm{NMe}_{2}$ function should lead to significant shifts for the proton (and/or carbon) resonances of the concerned moiety, as previously shown for rhodium complexes containing $\beta-\mathrm{P}, \mathrm{N}$ or $\gamma-\mathrm{P}, \mathrm{N}$ ligands $(\Delta \delta=2.5$ 
ppm for $\mathrm{NH}$ and $0.5 \mathrm{ppm}$ for $\mathrm{N}\left(\mathrm{CH}_{3}\right)_{2}$ protons $) .{ }^{6,12,24}$ On the other hand, the chemical shifts of both the $\mathrm{NH}$ and $\mathrm{NMe}_{2}$ protons for $\mathbf{1}^{\mathbf{A}}$ and $\mathbf{1}^{\mathbf{B}}$ were found to be identical to those of the corresponding free ligand.

<Insert Scheme 7>

The X-ray analysis of both complexes (figure 1), however, confirms that the ligand adopts a bidentate coordination mode via the $\mathrm{P}$ and $\mathrm{NH}$ donors in both cases, whereas the $\mathrm{NMe}_{2}$ group remains dangling. In contrast to complexes 2 (see below) the ${ }^{1} \mathrm{H}$ NMR resonances for the $\mathrm{NCH}$ CHP moiety give rise to a simple and distinct pattern for each isomer. Their ${ }^{3} J(\mathrm{H}, \mathrm{H})$ coupling constants are quite different, suggesting a near $180^{\circ} \mathrm{NCH}_{\mathrm{ax}}-\mathrm{CH}_{\mathrm{eq}} \mathrm{P}$ dihedral angle $(13 \mathrm{~Hz})$ for $\mathbf{1}^{\mathbf{A}}$ and a near $60^{\circ} \mathrm{NCH}_{\mathrm{ax}}-\mathrm{CH}_{\mathrm{ax}} \mathrm{P}$ dihedral angle $(5 \mathrm{~Hz})$ for $\mathbf{1}^{\mathbf{B}}$ in solution. ${ }^{33}$ This assignment corresponds to the geometry observed in the solid state.

Selected geometrical parameters are given in Table 2. Both structures show a nearly ideal square planar geometry around the rhodium atom. The largest discrepancy is along the $\mathrm{P}-\mathrm{Rh}-\mathrm{Cl}$ axis with angles of $174.46(2)$ and $173.57(2)^{\circ}$ for $\mathbf{1}^{\mathbf{A}}$ and $\mathbf{1}^{\mathbf{B}}$, respectively. The related complex $\left[\mathrm{RhCl}(\mathrm{CO})\left\{\mathrm{Ph}_{2} \mathrm{P}\left(o-\mathrm{C}_{6} \mathrm{H}_{4}-\mathrm{NMe}_{2}\right)-\kappa-P, \kappa-N\right\}\right]$ has a similar $\mathrm{P}-\mathrm{Rh}-\mathrm{N}$ angle of $174.7(2)^{\circ} .^{34}$ The $\mathrm{Rh}-$ $\mathrm{C}(3)$ bond lengths, on the other hand, are significantly shorter and the $\mathrm{C}(3)-\mathrm{O}(1)$ bond lengths are significantly longer than those of the above mentioned complex [Rh-C: 1.827(5) А; C-O: 0.989(5) $\AA],{ }^{34}$ suggesting that the $-\mathrm{CH}(\mathrm{Ph})-\mathrm{NHPh}$ function is transmitting more electron density to the metal center than the $-\mathrm{C}_{6} \mathrm{H}_{4}-\mathrm{NMe}_{2}$ function. This assertion is in agreement with the lower $v_{\mathrm{CO}}$ of $\mathbf{1}^{\mathbf{A}}$ (1983 $\left.\mathrm{cm}^{-1}\right)$ and $\mathbf{1}^{\mathbf{B}}\left(1993 \mathrm{~cm}^{-1}\right)$ relative to the above reported complex $\left(1995 \mathrm{~cm}^{-1}\right)$. Moreover, the strong coordination is also confirmed by a large decrease of $v_{\mathrm{NH}}\left(161 \mathrm{~cm}^{-1}\right.$ for $\mathbf{1}^{\mathbf{A}}$ and $140 \mathrm{~cm}^{-1}$ for $\mathbf{1}^{\mathbf{B}}$ relative to $\mathbf{L}^{\mathbf{3 A}}$ and $\mathbf{L}^{\mathbf{3 B}}$ free ligands). 


\section{$<$ Insert Figure 1>}

Since we have recently found examples of intra- and intermolecular $\mathrm{N}-\mathrm{H} \cdots \mathrm{Cl}-\mathrm{M}(\mathrm{M}=\mathrm{Rh}$, $\mathrm{Pd}^{\mathrm{II}}$ ) interactions, ${ }^{17,35}$ we have investigated the presence of this interaction in complexes $\mathbf{1}$ both in the solid state though the X-ray data and in solution through NMR and IR. No intramolecular N$\mathrm{H} \cdots \mathrm{Cl}-\mathrm{Rh}$ interaction exists in the solid state, since the $\mathrm{H}-\mathrm{N}(1)-\mathrm{Rh}-\mathrm{Cl}$ dihedral angle is very far from zero in both structures. The $\mathrm{H} \cdots \mathrm{Cl}$ distances (3.24-3.35 $\AA$ ) are quite close to the sum of the $\mathrm{H}$ and $\mathrm{Cl}$ van der Waal's radii (3.35 $\AA$ ). Furthermore, complexes with a genuine $\mathrm{N}-\mathrm{H} \cdots \mathrm{Cl}-\mathrm{M}$ intramolecular interaction in four-membered rings show $\mathrm{H} \cdots \mathrm{Cl}$ average values of $2.63 \AA{ }^{36}$ In principle, an intramolecular interaction could still be established in solution via a dynamic ring configuration exchange, by analogy with a similar $\mathrm{Rh}$ complex of the $\beta-\mathrm{P}, \mathrm{N}$ ligand (1R,2R)$\mathrm{Ph}_{2} \mathrm{PCH}(\mathrm{Ph}) \mathrm{CH}(\mathrm{Me}) \mathrm{NHMe},{ }^{12}$ leading to expected significant changes of the $\mathrm{H}-\mathrm{C}(1)-\mathrm{C}(2)-\mathrm{H}$ dihedral angles. However, the ${ }^{1} \mathrm{H}$ NMR spectra of our complexes $\mathbf{1}$ in $\mathrm{CDCl}_{3}$ solution show ${ }^{3} J(\mathrm{H}, \mathrm{H})$ coupling constants that, as mentioned above, are perfectly consistent with the corresponding solid state $\mathrm{H}-\mathrm{C}(1)-\mathrm{C}(2)-\mathrm{H}$ conformations according to the Karplus relationship. ${ }^{33}$

Thus, the NMR data indicate that the solid state structure is maintained in solution. This still leaves open the possibility of intermolecular hydrogen bonding interactions. Indeed, in the solid state, the three structures $\mathbf{1}^{\mathbf{A}}, \mathbf{1}^{\mathbf{B}}$ and $\mathbf{2}^{\mathbf{A}}$ (see below) stack in an almost identical fashion. Two coordination square planes are related by an inversion center showing a self-assembling interaction of two molecules by means of $\mathrm{N}-\mathrm{H} \cdots \mathrm{Cl}$ intermolecular hydrogen bonds (see Table 2). Infrared studies in $\mathrm{CH}_{2} \mathrm{Cl}_{2}$ solution, however, indicate that no hydrogen bonding is present. The $v_{\mathrm{NH}}$ bands at 3249 and $3270 \mathrm{~cm}^{-1}$ for $\mathbf{1}^{\mathbf{A}}$ and $\mathbf{1}^{\mathbf{B}}$ agree with a simple NH-Rh coordination mode. ${ }^{36}$

It is worth noting that the observed $\kappa^{2}-P, N(\mathrm{H})$ coordination mode generates a new asymmetric center at the $\mathrm{N}$ atom. Therefore, each ligand $\mathbf{L}^{\mathbf{3}}$ should yield in principle a mixture of two diastereomeric complexes. However, one diastereomer was obtained $\left(\mathbf{1}^{\mathbf{A}}\right.$ from $\mathbf{L}^{\mathbf{3 A}}$ and $\mathbf{1}^{\mathbf{B}}$ from 
$\mathbf{L}^{3 \mathbf{B}}$ ), indicating that the coordination reaction is highly (> 98\%) diastereoselective. This feature must be the result of a strong preference for placing the bulkier Ph group in the less congested, pseudo-equatorial position and the smaller $\mathrm{H}$ group in the pseudo-axial position. A high diastereoselectivity was also observed by us for the coordination of the simpler $\beta-\mathrm{P}, \mathrm{N}$, ligand $\mathbf{L}^{\mathbf{1}}$ to $\operatorname{Pd}(\mathrm{II}) .{ }^{17}$

\section{Coordination of ligands $\mathrm{L}^{5}$ to $\mathrm{Rh}(\mathrm{I})$}

The inseparable mixture of ligands $\mathbf{L}^{\mathbf{5}}$ reacts with $\left[\mathrm{RhCl}(\mathrm{CO})_{2}\right]_{2}$ to afford the corresponding complexes 2 [doublets at $42.4\left({ }^{1} J_{R h P}=166 \mathrm{~Hz}\right)$ for $\mathbf{2}^{\mathbf{A}}$ and $57.5 \mathrm{ppm}\left({ }^{1} \boldsymbol{J}_{R h P}=166 \mathrm{~Hz}\right)$ for $\mathbf{2}^{\mathbf{B}}$ ] in a ca. 55:45 ratio, i.e. very close to that of the two isomeric free ligands, see Scheme 8 . Like for complexes $\mathbf{1}$, a chelating coordination mode is indicated by the presence of only one (broad) carbonyl absorption band at $1985 \mathrm{~cm}^{-1}$ in the infrared spectrum. However, in contrast to complexes

1, the ${ }^{1} \mathrm{H}$ and ${ }^{31} \mathrm{P}$ NMR spectra show broad signals. The ${ }^{31} \mathrm{P}$ spectrum of the reaction mixture also shows the presence of small amounts of an unidentified complex $\mathbf{2}^{\prime}\left(\delta 47.36 \mathrm{ppm}\right.$ with ${ }^{1} J(\mathrm{Rh}, \mathrm{P})=$ $163 \mathrm{~Hz}$ ), in addition to the diastereomeric complexes 2. Crystallization from $\mathrm{CH}_{2} \mathrm{Cl}_{2} /$ pentane afforded single crystals of the major complex $\mathbf{2}^{\mathrm{A}}$. When these pure single crystals were dissolved in $\mathrm{CDCl}_{3}$, the ${ }^{31} \mathrm{P}$ NMR spectrum recorded after only 2 min shows a mixture of $\mathbf{2}^{\mathbf{A}}$ and $\mathbf{2}^{\prime}$ in an approximate 8:2 ratio (see also section 5). It cannot be established unambiguously, however, whether complex $\mathbf{2}^{\prime}$ forms rapidly from $\mathbf{2}^{\mathbf{A}}$ when this is dissolved, or whether the solid sample, which looks homogeneous at a visual microscope inspection, contained in fact another cocrystallized specimen. Cooling a toluene solution to $-30^{\circ} \mathrm{C}$ gave a microcrystalline powder which, upon dissolution and NMR analysis, consisted again of $\mathbf{2}^{\mathbf{A}}$ and the by-product $\mathbf{2}^{\mathbf{\prime}}$ in the same 8:2 ratio. However, both crystallization methods gave samples with no contamination by $\mathbf{2}^{\mathbf{B}}$. 
$<$ Insert Scheme 8>

The molecular structure of $\mathbf{2}^{\mathbf{A}}$ was elucidated by X-ray diffraction methods (see Figure 2). This demonstrates a $\kappa^{2}-\mathrm{P}, \mathrm{N}(\mathrm{H})$ chelating mode of the $\beta, \alpha-\mathrm{P}, \mathrm{N}, \mathrm{N}$, ligand, similar to that observed for complexes 1 , and establishes the $\left(S_{\mathrm{N}}, R_{\mathrm{C}}, R_{\mathrm{P}}\right)$ relative configuration for this diastereomer. Selected geometrical parameters for $2^{\mathrm{A}}$ are given in Table 2 . The geometry around the rhodium atom is similar to those of $\mathbf{1}^{\mathbf{A}}$ and $\mathbf{1}^{\mathbf{B}}$, with similar slight deviations from ideal. All bond lengths and angles of the coordination sphere as well as the P,N chelate moiety of $\mathbf{2}^{\mathbf{A}}$ are also quite similar to those found for $\mathbf{1}^{\mathbf{A}}$ and $\mathbf{1}^{\mathbf{B}}$. In particular, the Rh-C(3) and $\mathrm{C}(3)-\mathrm{O}$ bond lengths show once again the strong electron-donor character of the $-\mathrm{CH}(\mathrm{Ph})-\mathrm{NHPh}$ function. As discussed for $\mathbf{1}^{\mathbf{A}}$ and $\mathbf{1}^{\mathbf{B}}$, the geometry in complex $\mathbf{2}^{\mathrm{A}}$ is not compatible with an intramolecular $\mathrm{NH} \cdots \mathrm{Cl}$ interaction, but as observed for $\mathbf{1}$, two adjacent molecules are linked by intermolecular hydrogen bonds. The main difference with respect to complexes $\mathbf{1}$ is the position of the dangling amine function relative to the $\mathrm{Rh}$ atom. The small Rh-P-C(22)-N(2) dihedral angle $\left[44.2(2)^{\circ}\right]$ places the $\mathrm{N}(2)$ atom near the apical axis of the complex, at a relatively close contact with the Rh atom (3.66 $\mathrm{A})$. Even though this distance precludes $\mathrm{NEt}_{2}$ coordination to the metal center, the metal reactivity may be affected by the presence of this function (see section 6).

<Insert Figure 2>

Given the established $\left(S_{\mathrm{N}}, R_{\mathrm{C}}, R_{\mathrm{P}}\right)$ relative configuration for complex $2^{\mathrm{A}}$, a relative $\left(S_{\mathrm{N}}, R_{\mathrm{C}}, S_{\mathrm{P}}\right)$ configuration is attributed to diastereomer $\mathbf{2}^{\mathbf{B}}$. This attribution is based on the similar $\mathbf{2}^{\mathbf{B}} / \mathbf{2}^{\mathbf{A}}$ and $\mathbf{L}^{\mathbf{5 B}} / \mathbf{L}^{\mathbf{5 A}}$ ratios, suggesting the opposite relative configurations of the $\mathrm{P}$ and $\mathrm{C}$ chiral centers (as also happens for complexes $\mathbf{1}$ above), and on the demonstrated effect of the carbon configuration on that of the coordinated $\mathrm{N}$ atom. 
Even though a diastereoselective $\mathrm{N}$ coordination has been observed in this work for complexes 1 and previously on complex $\mathrm{PdCl}_{2}\left(\mathrm{Ph}_{2} \mathrm{PCH}_{2} \mathrm{CH}(\mathrm{Ph}) \mathrm{NHPh}\right),{ }^{17}$ the literature reports at least one precedent for diastereoisomers differing by the absolute configuration at the coordinated $\mathrm{N}$ atom, namely for complexes $\left[\mathrm{M}(\mathrm{COD})\left\{\mathrm{Ph}_{2} \mathrm{PCH}(\mathrm{Ph}) \mathrm{CH}(\mathrm{Me}) \mathrm{NHMe}\right\}\right]^{+}(\mathrm{M}=\mathrm{Rh}, \mathrm{Ir}) .{ }^{12}$ Therefore, it cannot be excluded that a ring conformer with a different absolute configuration at nitrogen is responsible for the minor product $\mathbf{2}^{\prime}$. The alternative interpretation of $\mathbf{2}^{\prime}$ as a dinuclear species containing $\mathrm{P}, \mathrm{N}$ bridges seems excluded because the relative intensities of all complexes do not significantly change upon fourfold dilution.

\section{Epimerization of complexes $2^{\mathrm{A}}$ and $2^{\mathrm{B}}$}

As stated above, the ${ }^{31} \mathrm{P}$ NMR analysis of a $\mathrm{CDCl}_{3}$ solution of single crystals of $\mathbf{2}^{\mathrm{A}}$ showed a 8:2 mixture of $\mathbf{2}^{\mathbf{A}}$ and $\mathbf{2}^{\mathbf{\prime}}$ after 2 min. However, the continued monitoring of this solution revealed further evolution, with appearance of the diastereomer $\mathbf{2}^{\mathbf{B}}$. The relative intensity of $\mathbf{2}^{\mathbf{B}}$ slowly increased with time while that of $\mathbf{2}^{\mathbf{A}}$ correspondingly decreased. The evolution stopped when the composition became identical with that of the crude product (see Figure 3). The filtrate of the crystallization process also exhibited the same product distribution.

$<$ Insert Figure 3>

This observation may be rationalized by inversion of either the skeletal $\mathrm{sp}^{3} \mathrm{C}$ atom or the $\mathrm{P}$ atom. As mentioned above, the skeletal $\mathrm{sp}^{3} \mathrm{C}$ inversion has at least one precedent in coordination compounds. ${ }^{33}$ There seem to be no precedent, however, for the racemization of a metal-coordinated chiral $\mathrm{P}$ atom. Of relevance is a previous report of a $\mathrm{P}$ atom inversion in a rhodium-coordinated tetraphosphine ligand, although the phosphorus center undergoing the inversion process does not 
appear to be formally coordinated to the metal. ${ }^{37}$ When the equilibrium mixture of $\mathbf{2}^{\mathrm{A} / \mathbf{B}}$ and $\mathbf{2}^{\mathbf{\prime}}$ in $\mathrm{CDCl}_{3}$ was treated with $\mathrm{D}_{2} \mathrm{O}$, the intensity of the $\mathrm{PCH}$ proton signals in the ${ }^{1} \mathrm{H}$ NMR spectrum remained unaltered even after twelve hours (which is much longer than the half-life of the epimerization reaction). This observation is inconsistent with a $\mathrm{CH}$ inversion. Since this $\mathrm{C}-\mathrm{H}$ bond is close to the metal center, it is possible to imagine a reversible oxidative addition to generate a $\mathrm{Rh}$ (III) hydride species. However, this process would not easily lead to inversion at carbon (this would require further $\alpha-\mathrm{H}$ elimination from the $\mathrm{Rh}$-coordinated amine function to generate an imine-dihydride intermediate, migration of the metal onto the opposite imine face, and reversal of the above processes).

The proposal of a $\mathrm{P}$ inversion seems more appealing. A first and obvious possibility consists of a reversible rupture of the $\mathrm{Rh}-\mathrm{P}$ bond to afford a $\kappa-N$ or a $\kappa^{2}-N, N$ coordination mode, followed by inversion at the free phosphorous atom and recoordination and since inversion barriers are high for free tertiary phosphines. ${ }^{32}$ This possibility, however, does not seem very likely since Rh(I)-P bonds are stronger than $\mathrm{Rh}(\mathrm{I})-\mathrm{N}$ bonds. Another way to accomplish the P-racemization is via a reversible P-C bond oxidative addition as shown in Scheme 9. The key transformation, formally analogous to an $\alpha$-alkyl elimination, is the transfer of the P-bound $\mathrm{CH}_{2} \mathrm{NEt}_{2}$ group onto the metal center, while the phosphine donor becomes a phosphido donor. The metal formally becomes $\mathrm{Rh}(\mathrm{III})$ along the process and the electronic unsaturation would be satisfied by $\pi$ donation from the P lone pair. As is well known, metal-phosphido moieties with a 4-electron $(\sigma+\pi)$ M-P bond adopt a planarat-P configuration. Subsequently, we need to invoke a ligand rearrangement in the 5-coordinate $\mathrm{Rh}(\mathrm{III})$ intermediate which places the $-\mathrm{CH}_{2} \mathrm{NEt}_{2}$ moiety on the opposite face of the phosphido plane, and final reversal of the P-C oxidative addition process. This proposed mechanism has close analogies with the recently reported $\mathrm{Rh}(\mathrm{I})$-catalyzed epimerization of $\mathrm{Ph}_{2} \mathrm{P}(\mathrm{E}) \mathrm{CH}(\mathrm{Ph}) \mathrm{NHCH}(\mathrm{Me}) \mathrm{Ph}$ $(\mathrm{E}=\mathrm{O}, \mathrm{S})$, which involves inversion at a chiral $\mathrm{C}$ center and seem to take place via a reversible P-C oxidative addition to $\mathrm{Rh}(\mathrm{I}) .{ }^{38}$ It is also relevant to mention here that $\alpha$-aminophosphines of the P-C- 
$\mathrm{N}(\mathrm{H})$ type have been shown to undergo reversible P-C bond cleavage. ${ }^{39,40}$ This mechanism also allows an additional possible interpretation of the "by-product" 2 ' as being the $\mathrm{Rh}(\mathrm{III})$ intermediate complex.

\section{<Insert Scheme 9>}

We should also consider the alternative possibility of a reversible $\mathrm{P}_{-} \mathrm{C}_{6} \mathrm{H}_{5}$ rather than $\mathrm{P}-\mathrm{CH}_{2} \mathrm{NEt}_{2}$ oxidative addition. Indeed, a related reversible $\mathrm{P}-\mathrm{Ph}$ bond activation was shown to take place with triaryl phosphine rhodium complexes at $120-130^{\circ} \mathrm{C}$ under propene hydroformylation conditions, leading to an aryl group exchange and to the formation of free $\mathrm{Ph}_{2} \mathrm{P}\left(\mathrm{C}_{3} \mathrm{H}_{7}\right){ }^{41,42}$ However, since the epimerization of $\mathbf{2}^{\mathbf{A}}$ occurs at room temperature, it seems reasonable to exclude this mechanistic pathway. It is important to underline that the solutions containing the $2^{\mathbf{A}} / \mathbf{2}^{\mathbf{B}} / \mathbf{2}^{\mathbf{2}}$ mixture are not indefinitely stable. After several hours, all signal intensities in the ${ }^{31} \mathrm{P}$ NMR spectrum decreased accompanying a color change from yellow to dark brown. A similar behavior was reported during the formation of phosphido compounds from $\mathrm{Rh}-\mathrm{PPh}_{3}$ complexes, giving rise to a clustering process. This observed instability is also the reason for the limited yield with which complex $2^{\mathrm{A}}$ was recovered.

\section{Catalytic properties in rhodium hydroformylation}

The newly developed $\beta, \gamma$ - and $\beta, \alpha$-diaminophosphines were used for preliminary studies of rhodium catalyzed styrene hydroformylation, in comparison with previously developed $\beta$ - and $\gamma$-aminophosphines, in order to find out whether the dangling nitrogen function can affect the activity and/or the selectivity. The relevant results are assembled in Table 3. All catalytic runs were carried out under identical conditions and in all cases the catalyst was prepared in situ by the 
reaction of $[\mathrm{RhCl}(\mathrm{COD})]_{2}$ with two equivalents of the appropriate $\mathrm{P}, \mathrm{N}$ or $\mathrm{P}, \mathrm{N}, \mathrm{N}$ ligands under syngas pressure. More detailed mechanistic investigations of this catalytic process with the aminophosphines complexes are underway and will be presented in due course.

\section{$<$ Insert Table 3>}

The results show that the product isomer ratio is always in favor of the branched isomer, as is usual for the Rh-catalyzed hydroformylation of styrene. ${ }^{43}$ The catalyst containing the $\beta, \gamma$ diaminophosphine $\mathbf{L}^{\mathbf{3 A}}$ has a comparable activity with the catalysts based on the $\beta$ - and $\gamma$-aminophosphines $\mathbf{L}^{\mathbf{1}}$ and $\mathbf{L}^{\mathbf{2}}$. The slight decrease of regioselectivity for the branched aldehyde observed for $\mathbf{L}^{\mathbf{3 A}}$ relative to $\mathbf{L}^{\mathbf{1}}$ and $\mathbf{L}^{\mathbf{2}}$ remains without a reasonable interpretation. This result would be rationalized if $\mathbf{L}^{\mathbf{3 A}}$ coordinates more strongly and/or exerts a greater steric hindrance. However, this does not seem to be comforted by the solid state structural data. The $\mathrm{NMe}_{2}$ group does not strongly affect the catalytic activity because of its remote position from the rhodium coordination sphere, as suggested by the X-ray investigation of the catalyst precursor (see Figure 1). On the other hand, the activity of the catalyst containing $\mathbf{L}^{\mathbf{5}}$ is three times greater than that of the catalyst containing $\mathbf{L}^{\mathbf{1}}$, while a high regioselectivity was maintained. As suggested by the molecular structure of the catalytic precursor $\mathbf{2}^{\mathrm{A}}$ (see Figure 2), the placement of the dangling $\mathrm{NEt}_{2}$ group close to the metal center may play a beneficial effect on the activity relative to the catalysts containing $\mathbf{L}^{\mathbf{1}}, \mathbf{L}^{\mathbf{2}}$ or $\mathbf{L}^{\mathbf{3 A}}$. We believe that the high basicity and the close proximity of this dangling nitrogen function to the metal center may facilitate a heterolytic dihydrogen activation, during the initial conversion of the $\mathrm{Rh}-\mathrm{Cl}$ precursor to the $\mathrm{Rh}-\mathrm{H}$ active species. Our current mechanistic studies intend to clarify the intimate action of this dangling amine group and to rationalize its beneficial effect in the rhodium-catalyzed hydroformylation process. 


\section{Conclusions}

We have described in this paper simple access routes to new classes of $\beta$-aminophosphines bearing a dangling nitrogen function $(\beta, \gamma-$ and $\beta, \alpha$-diaminophosphines), including the diastereoselective resolution by crystallization in the first case. All new diaminophosphines $\mathbf{L}^{\mathbf{3}}$ and $\mathbf{L}^{\mathbf{5}}$ adopt a chelating $\kappa-P, \kappa-N$ mode when binding the $\mathrm{RhCl}(\mathrm{CO})$ moiety, like the $\mathbf{L}^{\mathbf{1}}$ $\beta$-aminophosphine. The diastereomers obtained from $\mathbf{L}^{\mathbf{3 A}}$ or $\mathbf{L}^{\mathbf{3 B}}$, i.e. complexes $\mathbf{1}^{\mathbf{A}}$ and $\mathbf{1}^{\mathbf{B}}$, are stable in solution. However, when a phenyl group on the $\mathrm{P}$ atom is replaced by a $\mathrm{CH}_{2} \mathrm{NEt}_{2}$ fragment, i.e. in complexes $\mathbf{2}$, we have observed a relatively slow epimerization which we propose to involve inversion at the coordinated $\mathrm{P}$ atom. A remote $\mathrm{NMe}_{2}$ function (in ligand $\mathbf{L}^{\mathbf{3 A}}$ ) does not significantly modify the activity in rhodium catalyzed styrene hydroformylation. However, a relatively close but uncoordinated $\mathrm{NEt}_{2}$ function (in ligands $\mathbf{L}^{\mathbf{5}}$ ) increases the conversion rate by a factor of three. Although the latter ligand is more efficient in rhodium catalyzed styrene hydroformylation and it possesses an asymmetric P atom, it is not expected to induce large e.e.'s if used in the enantiomerically pure form, because of the established epimerization process. Further fundamental investigations are currently in progress in order to rationalize the beneficial effect of a dangling amine function, with the target of developing new active and enantioselective hydroformylation catalysts.

Acknowledgments. We are grateful to the Ministère de la Recherche, the Centre National de la Recherche Scientifique (CNRS) and the Conseil Regional de Bourgogne for financial support. We are also grateful to Cédric Balan for technical assistance. 


\section{References}

(1) Yang, H.; Alvarez, M.; Lugan, N.; Mathieu, R. J. Chem. Soc., Chem. Commun. 1995, 17211722.

(2) Yang, H.; Alvarez-Gressier, M.; Lugan, N.; Mathieu, R. Organometallics 1997, 16, 14011409.

(3) Hayashi, T.; Konishi, M.; Fukushima, M.; Kanehira, K.; Hioki, T.; Kumada, M. J. Org. Chem. 1983, 48, 2195-2202.

(4) Nagel, U.; Nedden, H. G. Chem. Ber. 1997, 535-542.

(5) Suomalainen, P.; Reinius, H. K.; Riihimäki, H.; Laitinen, R. H.; Jääskeläinen, S.; Haukka, M.; Pursiainen, J. T.; Pakkanen, T. A.; Krause, A. O. I. J. Mol. Catal. A 2001, 169, 67-78.

(6) Payne, N. C.; Stephan, D. W. Inorg. Chem. 1982, 21, 182-188.

(7) Arena, C. G.; Nicolò, F.; Drommi, D.; Bruno, G.; Faraone, F. J. Chem. Soc., Chem. Commun. 1994, 2251-2252.

(8) Kostas, I. D.; Screttas, C. G. J. Organomet. Chem. 1999, 585, 1-6.

(9) Scrivanti, A.; Matteoli, U.; Beghetto, V.; Antonaroli, S.; Scarpelli, R.; Crociani, B. J. Mol. Catal. A 2001, 170, 51-56.

(10) Drent, E.; Arnoldy, P.; Budzelaar, P. H. M. J. Organomet. Chem. 1993, 455, 247-253.

(11) Newkome, G. R. Chem. Rev. 1993, 93, 2067-2089.

(12) Dahlenburg, L.; Götz, R. J. Organometal. Chem. 2001, 619, 88-98.

(13) Habtemariam, A.; Watchman, B.; Potter, B. S.; Palmer, R.; Parsons, S.; Parkin, A. J. Chem. Soc., Dalton Trans. 2001, 8, 1306-1318.

(14) Albinati, A.; Lianza, F.; Berger, H.; Pregosin, P. S.; Rüegger, H.; Kunz, R. W. Inorg. Chem. 1993, 32, 478-486.

(15) Isslieb, K.; Kümmel, R.; Oehme, H.; Meisser, I. Chem. Ber. 1968, 101, 3612-3618. 
(16) Anderson, J. C.; Cubbon, R. J.; Harling, J. D. Tetrahedron: Asymmetry 2001, 12, 923-935.

(17) Andrieu, J.; Camus, J.-M.; Dietz, J.; Richard, P.; Poli, R. Inorg. Chem. 2001, 40, 1597-1605.

(18) Mansour, A.; Portnoy, M. J. Chem. Soc., Perkin Trans. 1 2001, 952-954.

(19) Yang, H.; Lugan, N.; Mathieu, R. Organometallics 1997, 16, 2089-2095.

(20) Bookham, J. L.; Smithies, D. M. J. Organometal. Chem. 1999, 577, 305-315.

(21) Braunstein, P.; Naud, F. Angew. Chem., Int. Ed. Engl. 2001, 40, 680-699.

(22) Bookham, J. L.; Smithies, D. M.; Pett, M. T. J. Chem. Soc., Dalton Trans. 2000, 975-980.

(23) Andrieu, J.; Steele, B. R.; Screttas, C. G.; Cardin, C. J.; Fornies, J. Organometallics 1998, $17,839-845$.

(24) Rauchfuss, T. B.; Patino, F. T.; Roundhill, D. M. Inorg. Chem. 1975, 14, 652-656.

(25) Sheldrick, G. M. SHELXS97. Program for Crystal Structure solution; University of Göttingen: Göttingen, Germany, 1997.

(26) Sheldrick, G. M. SHELXL97. Program for Crystal Structure refinement; University of Göttingen: Göttingen, Germany, 1997.

(27) Farrugia, L. J. J. Appl. Crystallogr. 1999, 32, 837-838.

(28) van der Sluis, P.; Spek, A. L. Acta Cryst. Sect. A: Found. Cryst. 1990, 46, 194-201.

(29) Barclay, C. E.; Deeble, G.; Doyle, R. J.; Elix, S. A.; Salem, G.; Jones, T. L.; Wild, S. B.; Willis, A. C. J. Chem. Soc., Dalton Trans. 1995, 57-65.

(30) Doyle, R. J.; Salem, G.; Willis, A. C. J. Chem. Soc., Dalton Trans. 1997, 2713-2723.

(31) Carmona, A.; Corma, A.; Iglesias, M.; Sanjose, A.; Sanchez, F. J. Organomet. Chem. 1995, $492,11-21$.

(32) Beachler, R. D.; Mislow, K. J. Am. Chem Soc. 1970, 92, 3090-3093.

(33) Haasnoot, C. A. G.; De Leeuw, F. A. A. M.; Altona, C. Tetrahedron 1980, 36, 2783-2792.

(34) Suomalainen, P.; Jääskeläinen, S.; Haukka, M.; Laitinen, R. H.; Pursiainen, J. T.; Pakkanen, T. A. Eur. J. Inorg. Chem. 2000, 2607-2613. 
(35) Andrieu, J.; Camus, J. M.; Richard, P.; Poli, R.; Baldoli, C.; Maiorana, S., in preparation.

(36) Fryzuk, M. D.; MacNeil, P. A.; Rettig, S. J. J. Am. Chem Soc. 1987, 109, 2803-2817.

(37) Hunt, C.; Fronczek, F. R.; Billodeaux, D. R.; Stanley, G. G. Inorg. Chem 2001, 40, 51925198.

(38) Andrieu, J.; Camus, J.-M.; Poli, R.; Richard, P. New J. Chem. 2001, 25, 1015-1023.

(39) Andrieu, J.; Dietz, J.; Poli, R.; Richard, P. New J. Chem. 1999, 23, 581-583.

(40) Andrieu, J.; Baldoli, C.; Maiorana, S.; Poli, R.; Richard, P. Eur. J. Org. Chem. 1999, 30953097.

(41) Abatjoglou, A. G.; Billig, E.; Bryant, D. R. Organometallics 1984, 3, 923-926.

(42) Abatjoglou, A. G.; Bryant, D. R. Organometallics 1984, 3, 932-934.

(43) van Leeuwen, P. W. N. M.; Claver, C., Eds. Rhodium Catalyzed Hydrofornylation; Kluwer: Dordrecht, 2000; Vol. 22. 
Table 1. Crystal data and structure refinement for all compounds.

Formula

$\mathrm{M}$; $\mathrm{K}$

Crystal system

space group

a; $\AA$

b ; $\AA$

$c ; \AA$

$\alpha ;{ }^{\circ}$

$\beta ;{ }^{\circ}$

$\begin{array}{ll}\gamma_{r} & \circ \\ V ; & \stackrel{\circ}{\AA}\end{array}$

$\mathrm{Z}$

F $(000)$

Dalc; $\mathrm{g} / \mathrm{cm}^{3}$

diffractometer

scan type

$\lambda ; \AA$

$\mu ; \mathrm{mm}^{-1}$

Crystal size; $\mathrm{mm}^{3}$

$\sin (\theta) / \lambda \max ; \AA^{-1}$

Index ranges

$\mathrm{RC}=$ Refl. Collected

IRC = unique RC / R(int)

IRCGT $=$ IRC and $[I>2 \sigma(I)]$

Refinement method

Data / restraints / param.

$\mathrm{R}$ for IRCGT

$R$ for IRC

Goodness-of-fit

$\Delta \rho, \max , \min ; \mathrm{e} . \AA^{-3}$

90

$\mathrm{C}_{35} \mathrm{H}_{33} \mathrm{~N}_{2} \mathrm{OPClRh} \cdot \mathrm{C}_{4} \mathrm{H}_{8} \mathrm{O}$

739.07

110

monoclinic

$\mathrm{P} 2{ }_{1} / \mathrm{C}$

$9.5846(1)$

$18.3642(2)$

$19.6147(2)$

$93.460(1)$

$3446.16(6)$

1528

1.424

Kappa CCD

\section{$1^{\mathrm{B}}$}

$\mathrm{C}_{35} \mathrm{H}_{33} \mathrm{~N}_{2} \mathrm{OPClRh} \cdot 1.5\left(\mathrm{C}_{4} \mathrm{H}_{8} \mathrm{O}\right)$

775.12

110

triclinic

$\mathrm{P}-1$

$11.8621(4)$

$12.7054(4)$

$12.9551(5)$

$75.371(1)$

$82.537(1)$

$78.473(1)$

$1844.6(1)$

2

1.396
$\mathrm{C}_{26} \mathrm{H}_{31} \mathrm{~N}_{2} \mathrm{OPClRh}$

556.86

110

oclinic

$\mathrm{P} 21 / \mathrm{C}$

$9.8922(1)$

$21.4323(3)$

$12.5571(2)$

90

$106.622(1)$

90

$2551.01(6)$

1144

1.450

mixture of $\phi$ rotations and $\omega$ scans

0.71073

$\begin{array}{ll}0.657 & 0.618\end{array}$

$0.25 \times 0.22 \times 0.20 \quad 0.45 \times 0.30 \times 0.30$

0.65

$\mathrm{h}:-12 ; 12$

$\mathrm{k}:-23 ; 23$

l: $-25 ; 25$

24975

$7871 / 0.0201$

7002

Full-matrix L.S. on $\mathrm{F}^{2}$

$7871 / 0 / 514$

$\mathrm{R} 1^{\mathrm{a}}=0.0253, \mathrm{wR}^{\mathrm{b}} \mathrm{b}=0.0627$

$\mathrm{R} 1^{\mathrm{a}}=0.0305, \mathrm{wR}^{\mathrm{b}}=0.0652$

1.030

0.99 and -0.54
0.65

$\mathrm{h}:-15 ; 15$

$\mathrm{k}:-16 ; 16$

1: $-16 ; 16$

13427

$8258 / 0.0236$

6479

$8258 / 0 / 435$

$\mathrm{R}^{\mathrm{a}}=0.0448, \mathrm{WR}^{\mathrm{b}}=0.1188$

$\mathrm{R}^{\mathrm{a}}=0.0582, \mathrm{wR}^{\mathrm{b}}=0.1248$

1.087

1.177 and -1.190
0.857

$0.50 \times 0.38 \times 0.25$

0.65

$\mathrm{h}:-12 ; 12$

$\mathrm{k}:-27 ; 20$

$1:-16 ; 12$

14013

$5785 / 0.0227$

4990

$5785 / 0 / 383$

$\mathrm{R} 1^{\mathrm{a}}=0.0252, \mathrm{WR}^{\mathrm{b}}=0.0552$

$\mathrm{R} 1^{\mathrm{a}}=0.0339, \mathrm{wR}^{\mathrm{b}}{ }^{\mathrm{b}}=0.0582$

1.010

0.457 and -0.546

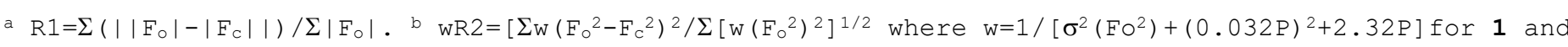

$\mathrm{w}=1 /\left[\sigma^{2}\left(\mathrm{FO}^{2}\right)+(0.063 \mathrm{P})^{2}+0.80 \mathrm{P}\right]$ for $1^{\prime}$ and $\mathrm{w}=1 /\left[\sigma^{2}\left(\mathrm{FO}^{2}\right)+(0.024 \mathrm{P})^{2}+1.33 \mathrm{P}\right]$ for 2 where $\mathrm{P}=\left(\mathrm{Max}\left(\mathrm{FO}^{2}, 0\right)+2 * F C^{2}\right) / 3$

c Goodness of fit $=\left[\sum \mathrm{W}\left(\mathrm{F}_{0}^{2}-\mathrm{F}_{\mathrm{c}^{2}}\right)^{2} /\left(\mathrm{N}_{0}-\mathrm{N}_{\mathrm{V}}\right)\right]^{1 / 2}$ 
Table 2. Selected bond lengths $[\AA ̊]$, angles [deg] and dihedral angles [deg] for all compounds.

\begin{tabular}{|c|c|c|c|c|c|}
\hline & $1^{\mathrm{A}}$ & $1^{B}$ & & $2^{\mathrm{A}}$ & \\
\hline $\mathrm{Rh}-\mathrm{P}$ & $2.2026(4)$ & $2.2041(8)$ & & $2.2075(5)$ & \\
\hline $\mathrm{Rh}-\mathrm{N}(1)$ & $2.1606(13)$ & $2.169(2)$ & & $2.1860(15)$ & \\
\hline $\mathrm{Rh}-\mathrm{Cl}$ & $2.3809(4)$ & $2.3758(7)$ & & $2.3954(5)$ & \\
\hline $\mathrm{Rh}-\mathrm{C}(3)$ & $1.8152(18)$ & $1.801(4)$ & & $1.796(2)$ & \\
\hline$C(3)-O(1)$ & $1.146(2)$ & $1.142(4)$ & & $1.155(2)$ & \\
\hline $\mathrm{N}(1)-\mathrm{H}$ & $0.89(2)$ & 0.70 & & $0.85(2)$ & \\
\hline $\mathrm{H} . . . \mathrm{Cl}$ & 3.25 & 2.98 & & 3.35 & \\
\hline $\mathrm{N}(1) \ldots \mathrm{Cl}$ & 3.22 & 3.23 & & 3.29 & \\
\hline H...Cla & 2.73 & 2.75 & & 2.57 & \\
\hline $\mathrm{N}(1) \ldots C 1^{\mathrm{a}}$ & 3.47 & 3.44 & & 3.39 & \\
\hline Other bond & & & & $\mathrm{N}(2) \ldots \mathrm{Rh}$ & \\
\hline $\mathrm{C}(3)-\mathrm{Rh}-\mathrm{N}(1)$ & $176.63(6)$ & $173.23(18)$ & & $175.25(7)$ & \\
\hline$C(3)-R h-P$ & $92.19(6)$ & $92.12(11)$ & & $91.36(6)$ & \\
\hline$N(1)-R h-P$ & $84.82(4)$ & $84.39(7)$ & & $84.01(4)$ & \\
\hline$C(3)-R h-C l$ & $93.01(5)$ & $93.24(12)$ & & $92.81(6)$ & \\
\hline $\mathrm{N}(1)-\mathrm{Rh}-\mathrm{Cl}$ & $90.03(4)$ & $90.64(7)$ & & $91.74(4)$ & \\
\hline $\mathrm{P}-\mathrm{Rh}-\mathrm{Cl}$ & $174.46(2)$ & $173.57(2)$ & & $174.44(2)$ & \\
\hline$O(1)-C(3)-R h$ & $179.37(17)$ & $176.6(5)$ & & $178.7 \quad(2)$ & \\
\hline $\mathrm{H}-\mathrm{N}(1)-\mathrm{Rh}-\mathrm{Cl}$ & $73(2)$ & $-52(1)$ & & $78(2)$ & \\
\hline \multicolumn{6}{|l|}{ Other angles } \\
\hline $\mathrm{H}-\mathrm{C}(1)-\mathrm{C}(2)-\mathrm{H}$ & $175(2)$ & $\mathrm{H}-\mathrm{C}(1)-\mathrm{C}(2)-\mathrm{H}$ & -47 & $\mathrm{Rh}-\mathrm{P}-\mathrm{C}(22)$ & $119.18(7)$ \\
\hline \multirow[t]{3}{*}{$\mathrm{H}-\mathrm{C}(1)-\mathrm{N}(1)-\mathrm{H}$} & $167(2)$ & $\mathrm{H}-\mathrm{C}(1)-\mathrm{N}(1)-\mathrm{H}$ & 172 & $\mathrm{P}-\mathrm{C}(22)-\mathrm{N}(2)$ & $109.69(13)$ \\
\hline & & & & $\mathrm{H}-\mathrm{C}(2)-\mathrm{N}(1)-\mathrm{H}$ & $-179(2)$ \\
\hline & & & & $\mathrm{Rh}-\mathrm{P}-\mathrm{C}(22)-\mathrm{N}(2)$ & $44.2(2)$ \\
\hline
\end{tabular}

a Atom of the closest symmetrically related molecule. 
Table 3. Catalytic properties of $\mathrm{P}, \mathrm{N}$ and $\mathrm{P}, \mathrm{N}, \mathrm{N}$ ligands in rhodium styrene hydroformylation ${ }^{\mathrm{a}}$

$\begin{array}{lcccc}\text { Ligand } & \text { Conversion }^{\mathrm{b}} & \text { TON } & \text { TOF }\left(\mathrm{h}^{-1}\right)^{\mathrm{c}} & \text { Regioselectivity }^{\mathrm{b}} \\ \mathbf{L}^{\mathbf{1}}(\beta-\mathrm{P}, \mathrm{N}) & 32 \% & 320 & 16 & 91 / 9 \\ \mathbf{L}^{\mathbf{2}}(\gamma-\mathrm{P}, \mathrm{N}) & 17 \% & 200 & 8.5 & 92 / 8 \\ \mathbf{L}^{\mathbf{3 A}}(\beta, \gamma-\mathrm{P}, \mathrm{N}, \mathrm{N}) & 24 \% & 240 & 12 & 86 / 14 \\ \mathbf{L}^{\mathbf{5 A} / \mathbf{B}}(\beta, \alpha-\mathrm{P}, \mathrm{N}, \mathrm{N}) & 87 \% & 870 & 50 & 91 / 9\end{array}$

${ }^{\mathrm{a}}[\mathrm{RhCl}(\mathrm{COD})]_{2}(12 \mathrm{mg})$, styrene/Rh/L $=1000 / 1 / 1, \mathrm{CHCl}_{3}(40 \mathrm{ml}), 55^{\circ} \mathrm{C}, \mathrm{CO} / \mathrm{H}_{2}=1,600$ psi. ${ }^{\mathrm{b}} \mathrm{The}$ regioselectivity is defined by the branched/linear ratio and measured after 20 hours. ${ }^{\mathrm{c}} \mathrm{TOF}$ calculated from the conversions at different times. 


\section{Captions for Figures}

Figure 1. ORTEP views of diastereomers $\mathbf{1}^{\mathbf{A}}$ (a) and $\mathbf{1}^{\mathbf{B}}$ (b). Thermal ellipsoids are drawn at 50\% probability level. For clarity, the solvate molecules are omitted and only relevant hydrogen atoms are shown.

Figure 2. ORTEP view of diastereomer $\mathbf{2}^{\mathrm{A}}$. Thermal ellipsoids are drawn at $50 \%$ probability level. For clarity, only relevant hydrogen atoms are shown.

Figure 3. ${ }^{31} \mathrm{P}$ NMR monitoring of the epimerization of diastereomer $\mathbf{2}^{\mathbf{A}}$ in $\mathrm{CDCl}_{3}$ solution. (a) After 2 min. (b) After 15 min. (c) After 5 h. (d) Crystallization filtrate or crude product. 
Figure 1
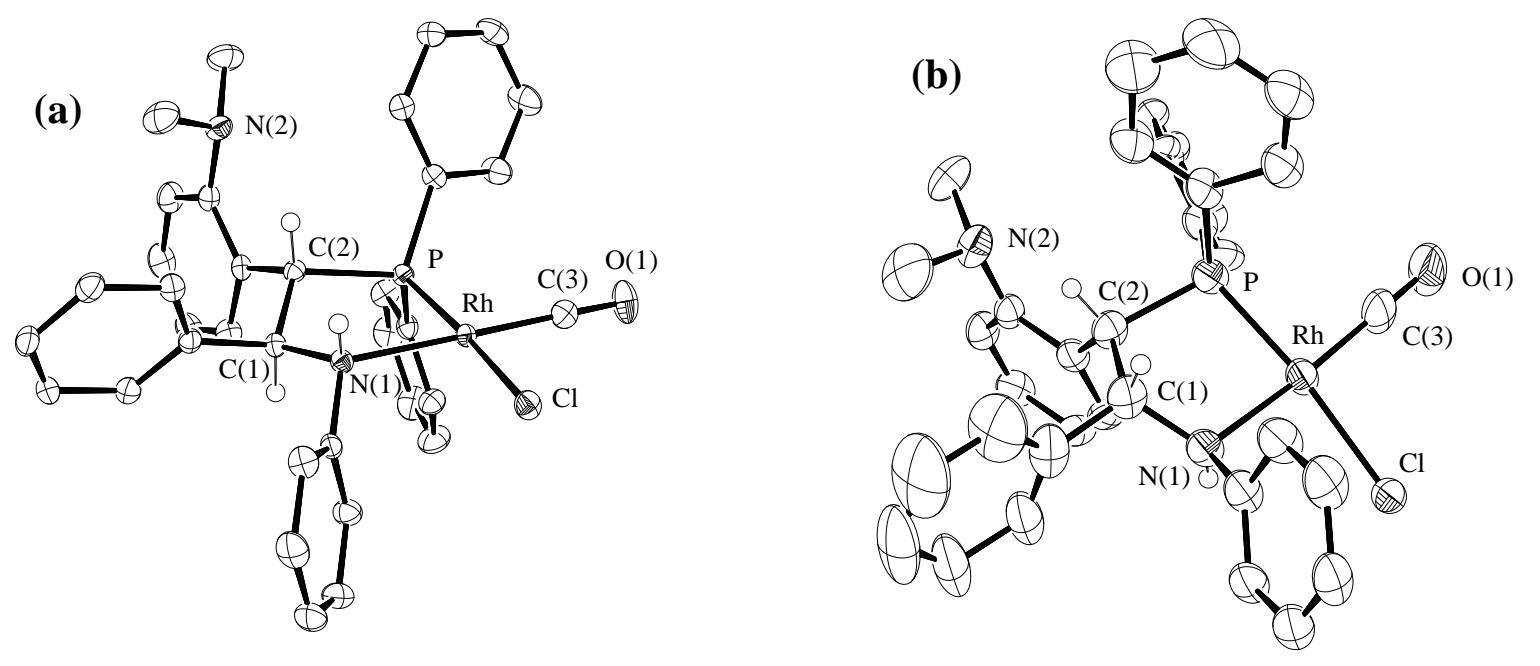

Figure 2

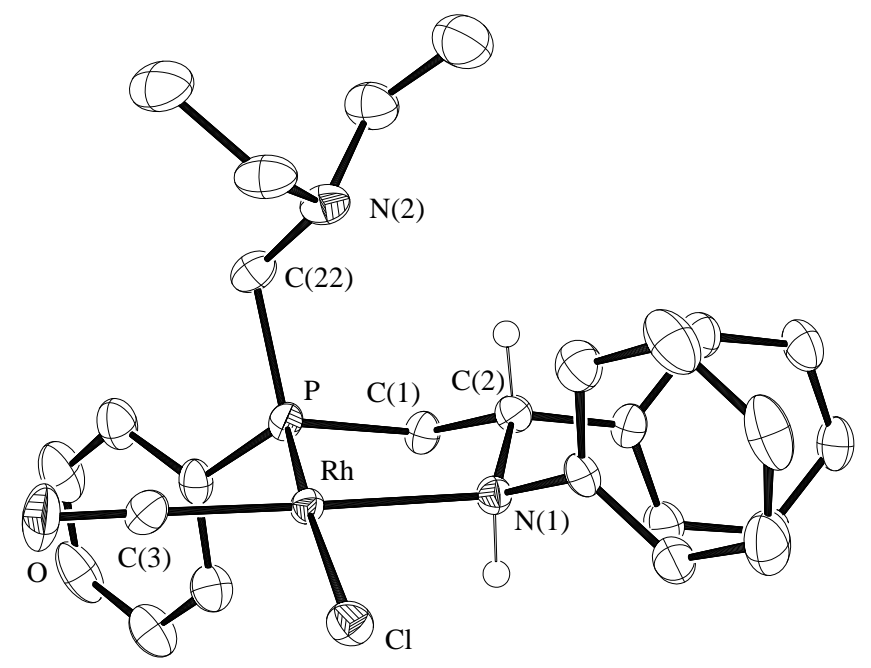


Figure 3

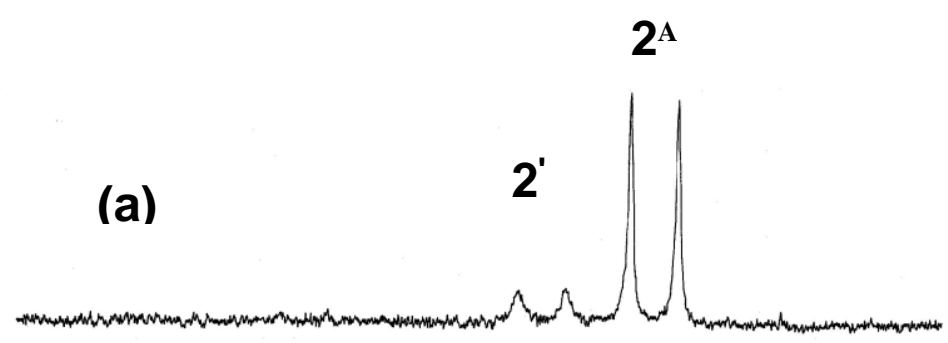

(b)

$2^{\mathrm{B}}$

(c)
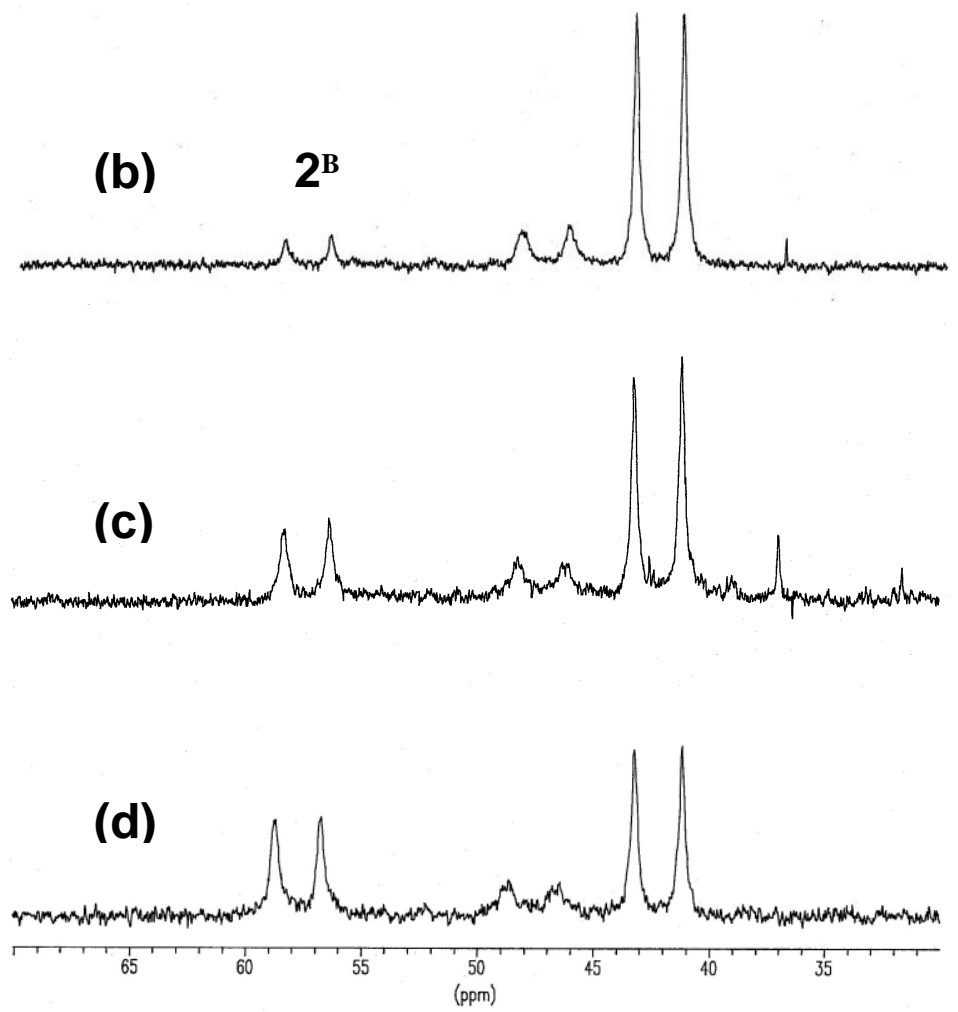
Scheme 1

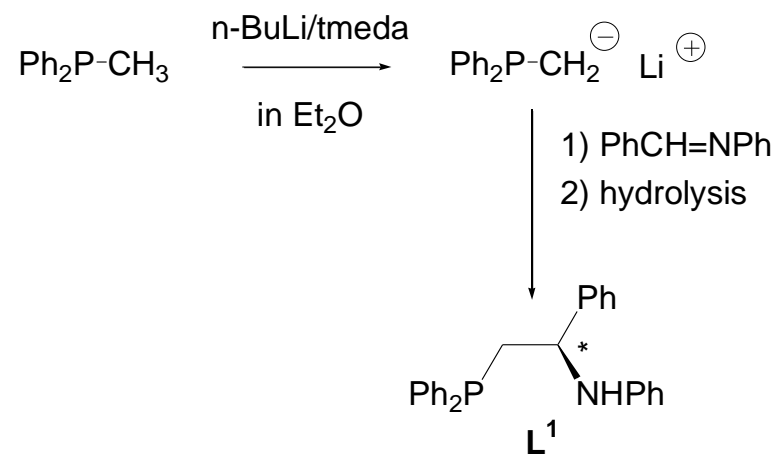

Scheme 2
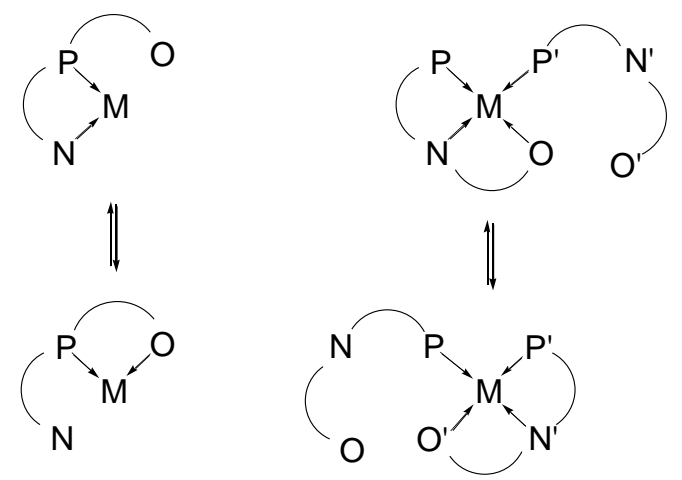

Scheme 3
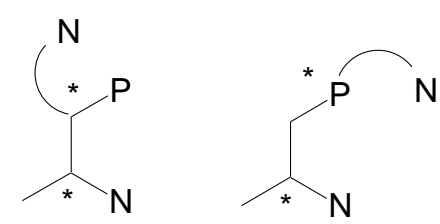

type I

type II 


\section{Scheme 4}
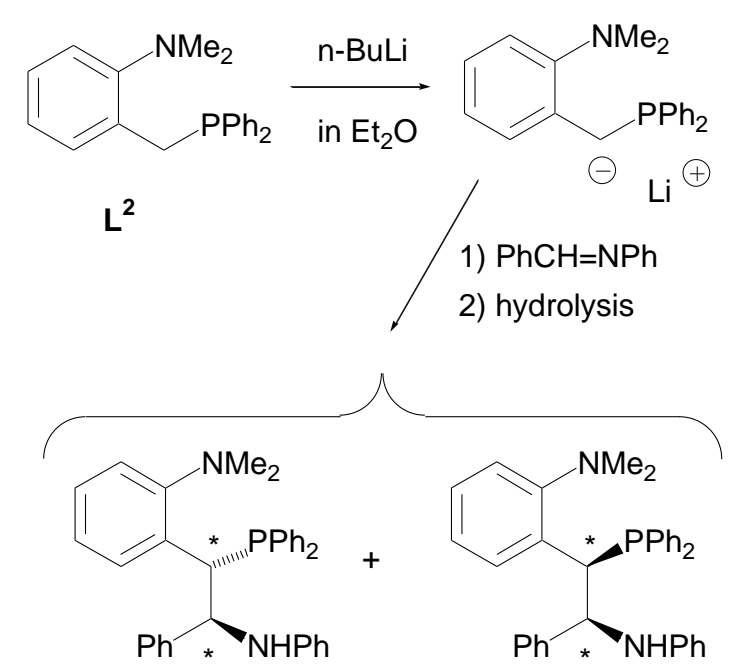

$\mathrm{L}^{3 \mathrm{~A}}\left(R_{\mathrm{C} 1}, R_{\mathrm{C} 2}\right) /\left(S_{\mathrm{C} 1}, S_{\mathrm{C} 2}\right) \quad \mathrm{L}^{3 \mathrm{~B}}\left(S_{\mathrm{C} 1}, R_{\mathrm{C} 2}\right) /\left(R_{\mathrm{C} 1}, S_{\mathrm{C} 2}\right)$

\section{Scheme 5}

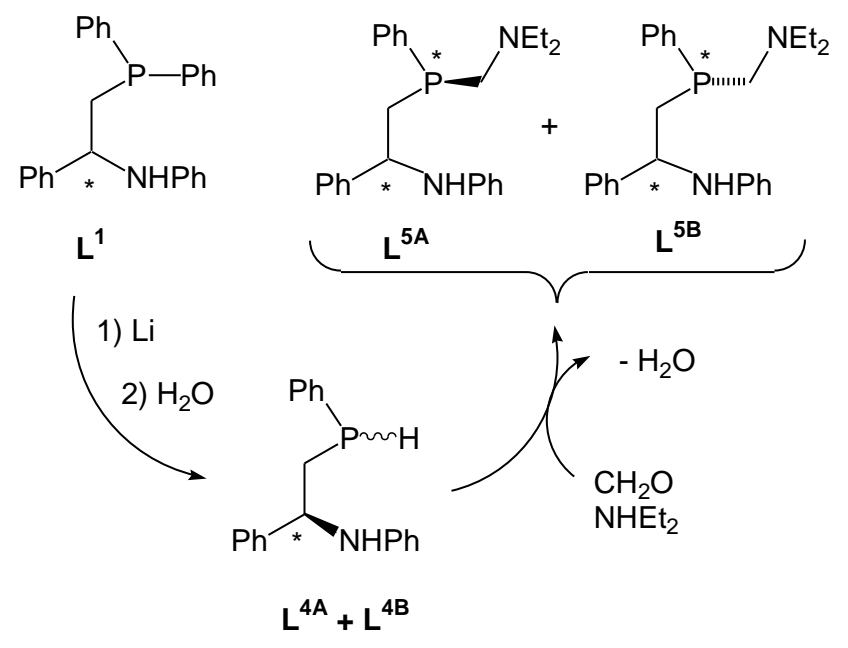




\section{Scheme 6}<smiles>CCNC[PH](C)(C/C(=N/c1ccccc1)c1ccccc1)c1ccccc1</smiles><smiles>CCN1CCN(c2ccccc2)C(c2ccccc2)C(C)P(c2ccccc2)C1</smiles>

$v \mathrm{NH}=3410 \mathrm{~cm}^{-1}$

$$
v \mathrm{NH}=3242 \mathrm{~cm}^{-1}
$$

\section{Scheme 7}

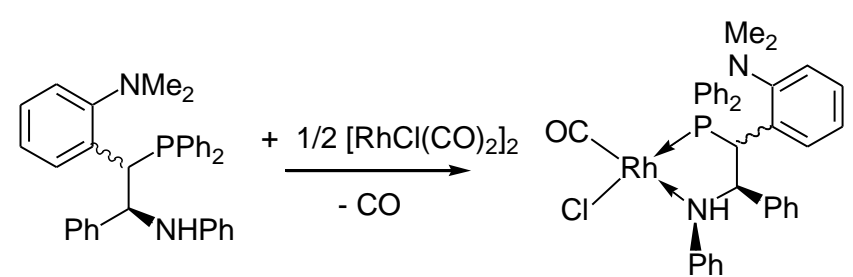

$\mathbf{L}^{3 \mathrm{~A}}\left(R_{\mathrm{C} 1}, R_{\mathrm{C} 2}\right) /\left(S_{\mathrm{C} 1}, S_{\mathrm{C} 2}\right)$

$1^{\mathrm{A}}\left(S_{\mathrm{N}}, R_{\mathrm{C} 1}, R_{\mathrm{C} 2}\right) /\left(R_{\mathrm{N}}, S_{\mathrm{C} 1}, S_{\mathrm{C} 2}\right)$

$\mathrm{L}^{3 \mathrm{~B}}\left(S_{\mathrm{C} 1}, R_{\mathrm{C} 2}\right) /\left(R_{\mathrm{C} 1}, S_{\mathrm{C} 2}\right)$

$1^{\mathrm{B}}\left(R_{\mathrm{N}}, S_{\mathrm{C} 1}, R_{\mathrm{C} 2}\right) /\left(S_{\mathrm{N}}, R_{\mathrm{C} 1}, S_{\mathrm{C} 2}\right)$ 
Scheme 8
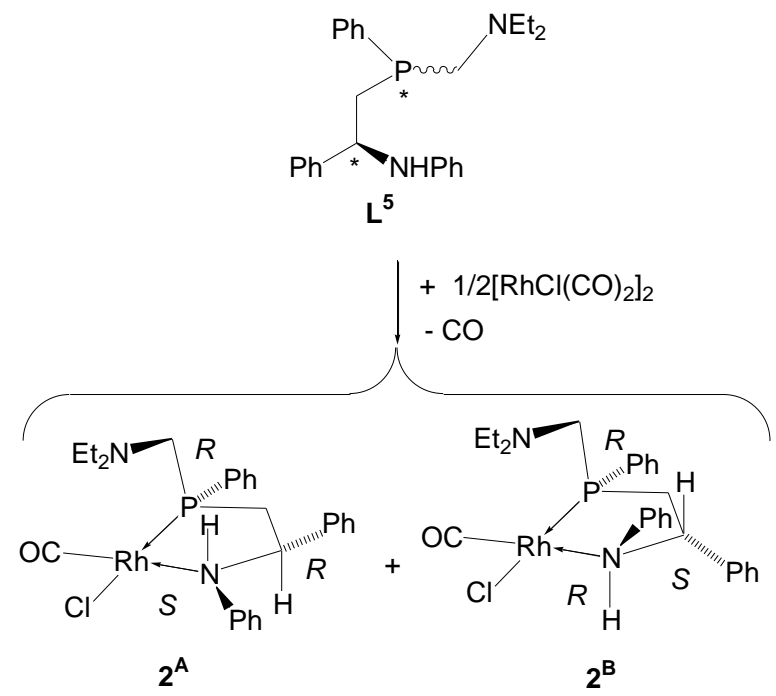

$\left(S_{\mathrm{N}}, R_{\mathrm{C}}, R_{\mathrm{P}}\right) /\left(R_{\mathrm{N}}, S_{\mathrm{C}}, S_{\mathrm{P}}\right) \quad\left(R_{\mathrm{N}}, S_{\mathrm{C}}, R_{\mathrm{P}}\right) /\left(S_{\mathrm{N}}, R_{\mathrm{C}}, S_{\mathrm{P}}\right)$

\section{Scheme 9}

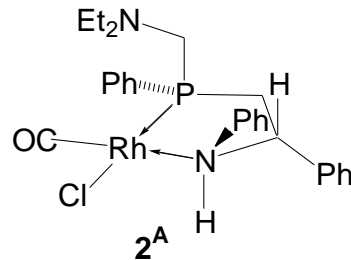

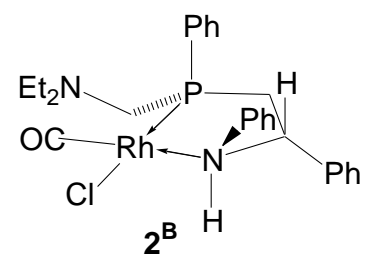<smiles>[CH]=C</smiles>

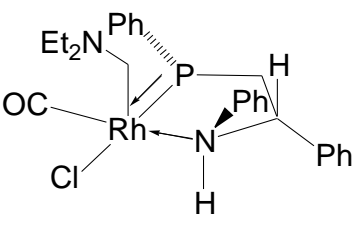

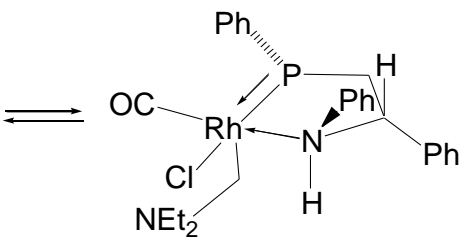

